\title{
Compensation and Buy-back Deals in Supply Chains: Analyzing Strategic Decision Areas by Using AHP
}

\author{
Erik Hofmann \\ University of St. Gallen (HSG), St. Gallen, Switzerland
}

\begin{abstract}
Practice reports suggest that the oldest form of trade - barter - is taking shape in supply chain management and production research. The paper highlights the phenomenon of countertrade in supply chains and takes first steps towards the conceptualization and explanation of a potentially powerful competitive tool - the analytic hierarchy process (AHP) - in practice.To test the construct, the model is applied to an illustrative case. The illustrations and the decision model shed light into why, and how, firms use countertrade in supply chains to support long-term business success. The identified forms of countertrade in supply chains exhibit different strengths with regard to a set of business objectives. The results contribute to the academic discussion of reciprocal agreements in supply chains as well as to the field of strategic production research in general. This paper should be of interest to practitioners as well as to academics specializing in supply chain management and strategic alliances in business networks.
\end{abstract}

Keywords: Barter, Countertrade, Industrial contract, SCM, Analytic hierarchy process.

\section{Introduction}

\section{Starting Point}

Since its introduction as a concept in the 1980s, Supply Chain Management (SCM) has undergone significant modification and expansion, reflecting the increasing importance of the discipline in academics as well as in practice (Stock et al., 2010). Indeed, one of the central trends in today's world is that competition is becoming less "firm vs. firm" and more "supply chain vs. supply chain" which coined the term strategic SCM (Hult et al., 2007). The emergence of SCM reflects a fundamental change from a perspective on a singular firm towards a processual, inter-organizational perspective on the supply chain as a whole. The goal of SCM is to improve operations management across several firms and functional boundaries on the network level, while reducing the supply chain's total costs and improving the quality and service of the output to its end-customers (Berry and Naim, 1996). As a result of increasing competition, firms become increasingly interconnected - a fact that offers new opportunities but also poses new challenges. The increased linkage between companies does not only dissolve functional and organizational boundaries between firms, but also increases the mutual dependency and vulnerability. Firms developed different, innovative approaches to cope with increased interdependency. 
A first example is the application of collaborative hedging strategies in international supply chain of the automotive industry. Recent research reports how a car manufacturer jointly trades with its smaller tier 1 supplier the raw materials from an upstream supplier against the output produced by the tier 1 supplier. Hence, the car manufacturer adopts an extended view of the supply chain and takes an intermediary position in the supplier network of its supplier (Hofmann, 2011).

A second example illustrates a mixture of reciprocal sales agreements in a counterpurchase agreement between a car retailer (Carco) and a telephone company (Telco). In one contract, Telco agrees to sell information and communication technology (ICT) products and services to Carco. In a second contract, Carco agrees to lease cars to Telco for the use of the marketing and sales agents. A third contract ties the two contracts together and specifies the terms of the exchange and settlement. For both Telco and Carco, this relationship represents a trade of a primary product or service against goods and services needed in a supporting activity.

These examples, involving two or more firms, have a specific characteristic: the supply chain relationship is characterized by a reciprocal exchange of goods or services. The oldest form of trade - barter - is taking shape in a broader context.

From the perspective of SCM, the seemingly outdated phenomenon of countertrade appears in a new light. "Countertrade" (CT) describes a range of arrangements where sales from one firm are linked to sales of another firm (Choi et al., 1999; Hennart, 1990; Hennart and Anderson, 1993). Mirus and Yeung (2001) describe the phenomenon as either an in-kind exchange of goods and services or as an interconnected bundling of transactions. Interest in CT in academic literature has ceased when this form of trade seemed to become obsolete after its highs during the cold war. Indeed, Samiee (2003) concludes that besides a limited number of studies which have been written from trade theory or finance perspectives, literature is almost void of CT analysis from a marketing point of view. A potential resurgence of the topic matter is noted by Sumer and Chuah (2007) that focus on legal challenges of reciprocal trade and discuss the overlap with new forms of finance. Nevertheless, an analysis of current CT forms from a SCM perspective does not exist.

\section{Contribution}

Recent news press, however, reports increased activities in the field of CT. Leading firms tap into the subject to enhance their competitive edge in today's markets and to increase value generation in their supply chain by restructuring both their relationships towards suppliers and customers. This indicates a need for a fundamental analysis of current CT strategies to fill the gap by both advancing supply chain theory and informing practice. In addition, a conceptual view is needed to shed light into how firms can leverage CT arrangements to get most out of their suppliers and customers, while increasing the value of the whole supply chain.

Hence, this paper thrives to answer the following research questions (RQ):

- RQ 1: Which CT alternatives have to be distinguished from a SCM perspective?

- RQ 2: How are business objectives linked to CT alternatives from a SCM perspective? 


\section{- $R Q$ 3: What strategic factors explain the choice of a specific CT alternative in} the context of SCM?

The purpose of this research from an academic perspective is to shed light into the forms and drivers of CT to conceptualize and explain this phenomenon in supply chains today. In order to answer RQ1, a conceptualization of the phenomenon from a theoretical perspective is developed to define and delimit the forms of CT in supply chains. Answering RQ 2, subsequently, research on underlying motivations and drivers is initiated to explain the existence of CT in supply chains. To answer RQ 3, a synthesis of both the conceptualization and the motivations of actors is needed to study the drivers behind a specific form of CT.

From a practical perspective, the purpose of this research is to specify the phenomenon of CT in supply chains today and explain the involvement of firms into its specific forms. The answer to RQ 1 should informpractitioners on the range of CT forms that a firm can apply in its supply chain. Resolving RQ 2 delineates the range of factors that $\mathrm{CT}$ influences and what specific objectives firms thrive to achieve in CT. The answer to RQ 3 supports the decision in practice on what CT form to choose in a supply chain relationship.

The applied research approach is the following. The lens of network perspective is suggested to conceptualize CT in supply chains. From this viewpoint, basic forms of $\mathrm{CT}$ are defined. In order to explain the existence the phenomenon and its application in supply chains today, a structured literature review is used to distill major objectives that have been identified in different research areas. Subsequently, the two perspectives are synthesized in a conceptual decision model that is formalized using the analytic hierarchy process developed by Saaty (1980). As a last step, the decision model for CT in supply chains is applied to an illustrative case to further test the concept and shed light into decisive factors in the application of $\mathrm{CT}$ in practice. The focus shall be on existing relationships in a supply chain between private companies. In particular, offset and other forms of government-mandated CT (e.g. clearing-, switch-trades) are out of scope of the paper at hand. Semi-structured interviews with trade and supply chain professionals were used to inform the study.

The paper is structured as follows: Next, Section 2 comprises a conceptualization of CT agreements. Section 3 provides the decision areas of CT. Then, a model based on the analytic hierarchy process is used to synthesize the two perspectives and to further conceptualize the use of countertrade (Section 4). To test the construct as well as to demonstrate the practical use of countertrade, the model is applied to illustrative cases (Section 5). The paper closes with a discussion and a brief summary in Section 6.

\section{Typology of Countertrade Deals}

\section{Conceptual Overview}

The network theory is suggested as an appropriate perspective to explore the phenomenon of CT as it appears in supply chains today (Fletcher, 1996). The terminology used in the academic discourse on CT has changed over the years due to new deal structures, different categorizations used in research, as well as different 
industry norms. Hence, the terminology used in this study is a proposition based on a supply chain network perspective (Håkansson and Persson, 2004).

- Actors - network nodes: Actors are situated on the nodes on either side of a network tie. In reciprocal forms of trade, each actor is both seller and buyer, depending on the perspective. For the sake of clarity, the actor situated in an earlier stage in the supply chain is named the seller; the firm more downstream is named the buyer.

- Relationships - network ties: Ties between network nodes are distinguished by different forms of interdependences. This paper uses the generic dimensions content (nature of exchanged goods and services) and quality (technological relationship) of the network relationship to distinguish different forms of CT.

The following terminology shall apply: a primary technological relationship of two goods or services exists if one good is produced using the other good (i.e. as a fixed asset) or one good serves as a primary input used in the production of the other good. A secondary technological relationship of the exchanged goods or services exists if one good is used in a supporting activity in the production of the other good but does neither serve as a production asset nor as a primary input. No technological relationship exists if the goods are not connected in any way. As this study concentrates on countertrade in supply chain networks, the existence of a primary or secondary technological relationship is a prerequisite. A discussion of a reciprocal exchange of goods or services without a primary or secondary technological relationship will be left aside.

Based on this terminology, a differentiation of basic CT deal structures with regard to the content and the quality of the relationship is feasible (see Figure 1).

Buy-back agreements are deals where the technological relationship of the exchanged goods or services is primary. Hence, in capital investment buy-backs (CiBBs), one good is used as a fixed asset in the production of the other good. In operating buy-backs (OpBB), one good is used as a primary input in the production of the other good (e.g. a raw material or other current asset). The category of compensation deals (CA) subsumes arrangements without a primary technological relationship. CAs could both involve an exchange of operating inputs or of capital investments and are called operating compensation deals, or capital investment compensation deals, respectively.

\section{Compensation Deals}

A compensation deal is characterized by the exchange of operating inputs or capital investments (content) that share no primary technological relationship (quality) between two or more actors in a supply chain network. Following the classical terminology, the two major forms of compensation deals are barter and counterpurchase. An increasing trend, and special case, in the area of compensation deals is the growing popularity of barter exchanges, also called local exchange trading schemes (LETS). Using current examples, the concept of compensation deals shall be illustrated in more detail.

In CT literature, barter is defined as a direct, simultaneous exchange of products or services of approximately equal value between two actors (cf. Reisman et al., 


\begin{tabular}{|c|c|c|c|}
\hline & & \multicolumn{2}{|c|}{ Quality (technological relationship) } \\
\hline & & Primary & Secondary \\
\hline \multirow{2}{*}{$\begin{array}{l}\overrightarrow{0} \\
\stackrel{0}{0} \\
0\end{array}$} & $\begin{array}{l}\text { Operating } \\
\text { inputs } \\
\text { (OPEX) }\end{array}$ & $\begin{array}{c}\text { Operating } \\
\text { buy-back, } \\
(\mathrm{OpBB})\end{array}$ & \multirow{2}{*}{$\begin{array}{l}\text { Compensation } \\
\text { deals (CA): } \\
\text { - Operating CA } \\
\text { - Capital } \\
\text { investment CA }\end{array}$} \\
\hline & $\begin{array}{c}\text { Capital } \\
\text { investments } \\
\text { (CAPEX) }\end{array}$ & $\begin{array}{c}\text { Capital } \\
\text { investment } \\
\text { buy-back } \\
\text { (CiBB) }\end{array}$ & \\
\hline
\end{tabular}

Figure 1. Taxonomy of countertrade deals.

1988; Lecraw, 1989; Paun, 1997). Reisman et al. (1988) define a classical barter more precisely as a short-term and bilateral trade that excludes financing and technology transfer. Sumer and Chuah (2007) note that in most commercial transactions that involve barter, goods are valued separately rather directly in terms of each other. Conventionally, barter involves only one contract, which is the main difference to a counterpurchase. Following the supply chain network logic, a barter transaction is not necessarily bilateral. In addition, the short-term aspect is not an effective criterion to distinguish barter agreements in supply chains. These features shall be exemplified by an CT agreement in the media industry. A cinema trades advertising spot time against advertising space with a newspaper company. Using the network terminology, two actors in a horizontal supply chain relationship decide to leverage the reciprocity of their network tie. The cinema and the newspaper company utilize a barter agreement to coordinate the bilateral exchange of services. The traded advertising space serves a supporting activity in both companies and is part of the operating budget. What is the rationale for both companies to enter such a deal? It could be to develop a new market segment by using a new advertising channel, to facilitate marketing activities for a new product (e.g. 3D-cinema, or a new weekly magazine), to lower total marketing cost, and also to commit to a long-term partnership to secure advertising space on a continuous basis.

Counterpurchase is another specific form of an CA. In a counterpurchase, firms assume mutual obligations to purchase products from each other by means of two separate but tied contracts (Lecraw, 1989). These two contracts are linked together in a third contract (Fletcher, 2009) and settlement is typically in cash (Paun and Shoham, 1996; Paun et al., 1997). Neale and Sercu (1993) describe counterpurchase as a derivative of classical barter in which goods are always valued in monetary terms. More recently, Baranowska-Prokop (2009) characterizes counterpurchase as an agreement by the initial seller to buy a specified value of goods (often stated as a percentage of the initial sales volume) from the initial buyer over a defined period of time. Companies follow different rationales to enter a counterpurchase agreement. If the motivation is clearly sales-driven this form of trade is also called reciprocal sales agreement (Sumer and Chuah, 2007). Also, a financing rationale could be a primary driver to enter a counterpurchase agreement, as shown by Reisman et al. (1988). In this case, a first contract settles the sale of company A's products against credit to company B. A second 
contract defines the sale of company B's products against credit to company A. The two contracts are tied in a third contract that also defines the credit terms and final settlement in hard currency (Choi and Tschoegl, 2003). That form of CT is in principle a counterflow of finance (Neale and Sercu, 1993). But why should companies entering such a deal? The rationale could be to establish a stronger mutual customer relationship, gain favorable terms of trade, or install a favorable financing agreement.

\section{Operating Buy-backs}

Firms use an operating buy-back agreement to structure a supply chain relationship in a situation of reciprocal dependence with regard to primary business inputs or outputs (i.e. in case of a primary technological relationship). One partner supplies an input factor to the production and is later compensated by means of the processed output. This output is then used either in the production of the initial supplier (direct usage), or is forwarded to a cooperating party (indirect usage). As opposed to a capital investment buy-back, an operating buy-back concerns operating expenditure (e.g. input materials or pure operating cost items in the case of services).

Classical CT literature is scare of research in the area of these agreements. A form of operating buy-backs exists in the raw materials industry where the practice is known as tolling agreements. In SCM, however, the phenomenon has been taken up recently under the name of supply chain sourcing and natural hedging (Hofmann, 2011). This form of operating buy-backs has been found in several industries, like electronics, pharmaceutical and automotive industries.

In the food industry, operating buy-backs are used to facilitate the trade of agrichemical products and seeds to farmers. Ligi and Kolesnikova (2009) report how a crop and fertilizer producer uses operating buy-back agreements in its sales of seeds as well as crop protection chemicals to associations of farmers in Brazil and Eastern Europe. Seeds are a primary input to the production of soy beans in Brazil, and crop protection chemicals support the stable growth of the plants. In spring, farmers receive both new seeds and crop protection products from the producer. Later on, in autumn, the farmers sell an agreed part of their output back to the producer that forwards these proceeds to a trading company acting as a cooperation partner in this deal. For the farmers, the decision to enter the agreement could be technology-driven (e.g. access to newest generation of farming products), or finance- and supply chain cost-driven (e.g. access to implicit financing, assurance of a future sales contract). For the producer, the decision to enter the deal could be driven by marketing and sales reasons (e.g. increase sales of new products or avoid pressure on margins), or could follow a more strategic rationale (e.g. develop Brazil as a main market, increase bargaining power against farmers associations).

\section{Capital Investment Buy-backs}

If the reciprocal ties between two or more actors in a supply chain network are characterized by a primary technological relationship and at least one exchange of a fixed asset, the involved firms could use a capital investment buy-back agreement to structure their relationship. The classical form of industrial buy-back agreements is one form of these relationships, where the initial seller builds production capacity 
and the initial buyer pays for the investment by means of produced products (Paun, 1997). Descriptions of classical buy-back agreements in literature mostly involve the construction of a manufacturing plant and the subsequent compensation of the plant building and maintenance cost by means of a specific share of the produced output. The use of the output is either direct (used in production of the buyer) or indirect (e.g. sold through a cooperation partner). Installing a capital investment buy-back structure could lead to a similar result as agreeing on a joint venture as Reisman et al. (1988) noted. From a legal perspective, a buy-back agreement is usually composed of three contracts similar to a counterpurchase - two purchasing contracts and one overarching framework contract tying these two together (Forker, 1996, 1997).

As an example of a capital investment buy-back in the raw materials industry, a mining and exploration company (MEC) agrees with a land owning party and mine operator (MO) to trade a complete operational mine against a share of the extracted commodity for a specific period of time. A service provider acts as an orchestrator, both organizing the trade as well as selling the proceeds of the mine on the world market. Hence, a capital investment (i.e. the mine) is traded against its production output (i.e. the raw material). In supply chain network terms, the capital investment buy-back helps the two actors to leverage the potential of their vertical relationship. Why would each actor enter the agreement? The decision by the exploration and mining company could be driven by a marketing and sales rationale (e.g. support sales of new mining technology), or market strategy (e.g. gain stronger foothold a specific market). On the other hand, the rationale for the land owner and mine operator could be technology related (e.g. gain access to new mining technology), or financially driven (e.g. access to financing). And finally, the cooperation partner's motivation to orchestrate this capital investment buy-back could be based on a marketing and sales rationale (e.g. achieve higher margins) or related to supply chain objectives (e.g. secure stable future supply streams).

\section{Decision Areas of Countertrade Deals}

The taxonomy and brief practical examples not only illustrated various applications of CT in different industries but also portrayed a first set of potential business objectives that drive firms to choose a CT arrangement to structure their supply chain relationships. However, what are specific decision factors that firms take into account when agreeing on a CT deal? Still, CT is not a ubiquitous phenomenon and its profitability for the involved partners has often been put into question (Khoury, 1984; Yavas and Freed, 2001).

In a contemporary supply chain setting, the rationale to choose a specific $\mathrm{CT}$ arrangement exceeds structural reasons or static conditions. Moreover, a proactive approach suggests that CT is used as a tool to achieve specific business goals. Hence, an investigation of the business objectives that lead firms to use a CT deal structure in its supply chain is needed.

Building upon the fundamental objective of a market participant to maximize long-term profits from the resources employed, the different ratios of the return on assets (ROA) approach are used to underpin the relevant decision areas of CT. The ROA decomposition follows Teague and Eilon (1973) and Slack and Lewis (2008): 


$$
R O A=\left(\frac{\text { Revenue }}{\text { Output }}-\frac{\text { Cost }}{\text { Output }}\right) \times \frac{\text { FixedAssets }}{\text { TotalAssets }} \times \frac{\text { Output }}{\text { FixedAssets }}
$$

The revenue/output ratio, or average revenue margin, increases whenever a firm is able to sell its goods or services at a marginal higher price per unit. To improve overall profitability, measures that allow a firm to charge a marginally higher price per unit or sell output more effectively will increase the average revenue margin. Hence, a first Strategic Decision Area (SDA) - Marketing and Sales (M\&S) - subsumes business objectives that ultimately aim at increasing ROA by raising the average revenue margin.

The cost/output ratio, or average cost margin, decreases whenever a firm is able to reduce total cost per unit of output. Hence, to increase ROA, firms take measures to decrease the total cost associated to the production of output (e.g. material input cost, transaction cost) or increase production at marginally lower cost. A second SDA - Supply Chain Operations (SCO) - shall reflect those business objectives that aim at raising ROA by reducing the average cost margin.

The fixed assets/total assets ratio is a measure of capital allocation decisions and of how efficiently the working capital of a company is used. When a firm is able to produce the same output while employing a smaller working capital, fixed assets are closer to total assets. In particular, firms that develop and manage closer ties to up- or downstream business partners are able to decrease inventories (and increasing inventory turnover) or decrease accounts receivables. In addition, how much capital a firm holds in the longer term is less a financial decision than it follows a strategic rationale (e.g. make-or-buy decisions). For example, a firm that accesses another firm's distribution network expands its market without increasing the capital employed. Hence, a third SDA is identified - network relationships (NRS). This decision area subsumes business objectives that aim increasing ROA by managing old and creating new network relations and concern long-term capital investments.

The output/fixed assets ratio is a measure of productivity of fixed assets. ROA increases whenever a firm is able to produce a marginally higher output using the fixed assets employed. Firms use innovation processes and utilize new technologies to increase the productivity of fixed assets. The fourth SDA - Technology and Innovation (T\&I) - includes business objectives that aim at raising the ROA by increasing the productivity of the fixed assets.

Obviously, the categorization is not clear-cut. Measures that are taken following purely one rationale could support but also hamper the outcome in other areas. However, the categorization is useful to connect strategic decisions to a firm's fundamental drivers of business success. In this regard, the four decision areas rationalize the engagement of companies in reciprocal trade structures and support a firm's choice of a specific deal structure with a strategic and business-driven foundation. The four SDAs are used as a frame to structure the business objectives for CT from a SCM perspective.

A structured literature review distilled twelve major business objectives - three in each SDA (Appendix 1 and Figure 2):

- $M \& S$ : Volume Management (VM), Pricing (P) and New Product Support (NPS); 


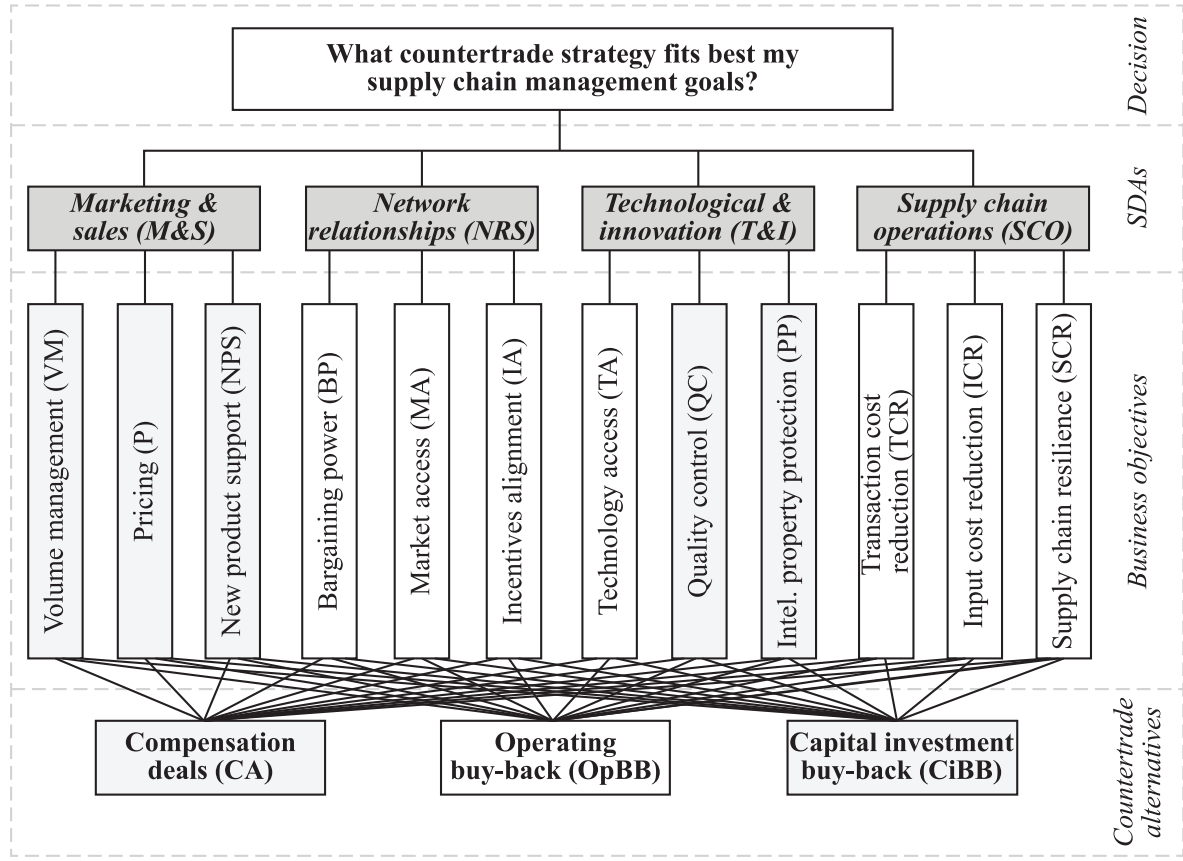

Figure 2. AHP methodology applied to countertrade in supply chains.

- NRS: Bargaining Power (BP), Market Access (MA) and Incentives Alignment (IA);

- T\&I: Technology Access (TA), Quality Control (QC) and Intellectual Property Protection (IPP);

- SCO: Transaction Cost reduction (TCO), Input Cost Reduction (ICR) and Supply Chain Resilience (SCR).

A proactive, business-driven approach to CT suggests that firms chose one of the three deal structures based on specific objectives in each decision area. Hence, a synthesis of the three types of countertrade deals and the objectives along the four SDAs is needed. AHP is used to structure the strategic decision-making process with regard to the choice of a specific CT deal structure.

\section{Decision Making by Using AHP}

\section{AHP Foundation}

To solve a Multi Criteria Decision Making (MCDM) problem, a number of models has been used in research and applied in practice. King and Sivaloganathan (1999) identified five main types of concept selection methods for use in business practice: utility theory, analytic hierarchy process (AHP), graphical techniques using matrices, quality function deployment, and fuzzy logic. 
The Analytic Hierarchy Process (AHP) is a specific MCDM approach based on a hierarchical problem structure and pairwise comparison judgments between decision factors. It is used both to structure a decision problem as well as it provides a model that is applicable to managerial decision making. The introduction to AHP and the subsequent application on decision making for countertrade in supply chains is based on a revised version of the initial approach published by Saaty and Vargas in 2001. To manage the complexity the decision-making process breaks the problem down into levels of decision criteria that can be managed more easily (Boardman et al. 2008; Wang 2001):

- Problem decomposition and hierarchy construction: The idea of AHP is to reduce complexity by downsizing multi-factorial problems into different levels of hierarchy. On the top level of the hierarchy will only be one element, this element defines the task of the evaluation process. One level lower the elements are called criteria, each of them can be broken down into sub-criteria. The lowest level of the hierarchy includes alternatives or scenarios, these are the decision options.

- Determine alternatives and scenarios: At this step of the AHP different alternatives are defined. Satty's (1980) recommended limit for the number of alternatives/ scenarios should not exceed 20 elements of weighting.

- Pair-wise comparison: In order to determine the relative importance of the elements the pair-wise comparison procedure starts within each level. The judgment starts form the first level of criteria and ends with the alternatives. Based on their level of influence and on the specified element in the higher level the elements are compared pair-wise. To compare the elements the preference between each pair must be expressed.

- Weight calculation: Satty's 1 to 9 scale, normalization method and inverse normalization method are used to find the priority weights for each matrix. Satty's preference scale (1980) allows defining the relative importance of competitive priorities and the performance measures can be expressed.

- Consistency check: In this step the quality of the results are checked. If the consistency ratio value is higher than 0.10 , the possibility that the elements have not been compared properly is about 10 percent. This is the upper limit for the consistency ratio (Saaty, 1980). In this case the different comparisons have to be reviewed.

- Hierarchical synthesis: In order to develop an overall evaluation process the mathematical process starts to integrate the assigned weights.

- Determine priorities for all alternatives: In the last step the decision-maker can choose the alternative with the highest priority number. This number results out of the mathematical deployment.

\section{AHP Research in SCM}

AHP is common in the field of SCM. Appendix 2 shows the results of a brief literature review on two databases, namely ProQuest and EBSCO. The terms used for the search engines were: AHP and supply chain and analytical hierarchy process and supply chain. 
Most of the published research papers in the last five years used a single AHP approach for the decision making process in the various areas around the issues of SCM. Some authors already combined the multi-criteria decision making tools with other management tools.

Most papers are not focused on any industry and if they are they work in similar ones. There are branches like the automobile industry which did not have any noteworthy attention in the research community. Still this branch has to coordinate complex supply chains and could therefore use customized decision frameworks. For the design of decision tools the underlying industries have to be analyzed and understood very accurately. Every branch has its characteristics, so they have to be respected while providing management support. A more detailed specialization of the provided tools could add additional value for practitioners.

A lot of different issues among supply chains were studied. A significant amount of research papers provide solutions for selection problems within suppliers, partners, and logistics providers as well as production locations. In the recent years the topic of green supply chains management gained attention. Therefore models were provided to design environmental friendly supply chains. Also strategic questions like the level of information sharing or the optimization of horizontal collaboration were discussed. Still in these high-level questions further research can be done.

A MCDM or AHP model focusing CT deals - especially in the automotive industry - cannot be found in literature.

\section{Decision Model for Countertrade Deals}

\section{Background}

AHP has been developed by Thomas L. Saaty in the 1970s for decision making in military contingency planning, scarce resources allocation, and in political disarmament agreements (Saaty, 1980). Since then, AHP has been used as a multiplecriteria decision analysis tool in research areas as different as architectural design, political sciences, and macroeconomic forecasting (Saaty and Vargas, 2001). This paper used an AHP approach to both study a firm's decision with regard to the choice of a specific CT deal structure, as well as to provide an approach for practical decisionmaking in this field. The benefits of an AHP approach are manifold. First, the need to structure a problem in a thorough analytical manner forces a decision maker to define a problem and its decisive factors both precisely and extensively. By using AHP, a decision maker is able to analyze a problem in depth and breadth without either losing the big picture or getting lost in details. Second, AHP is able to include both quantitative measures and qualitative judgments in one holistic decision model. It is applicable in both quantitative sciences as well as social domains (Saaty and Vargas, 2001). Third, AHP unveils inconsistency in the judgments. The built-in consistencychecking mechanism allows management to identify inconsistencies at very early stages of the process (Palliam, 2005). Furthermore, AHP provides a framework for group decision making. An AHP approach facilitates the involvement of subject matter experts for specific judgments as well as it provides a framework to consolidate individual judgments to form a collective decision (Saaty and Vargas, 2006). In addition, it facilitates visualization of the impact of various criteria on the final result. 


\section{AHP for Countertrade}

Based on the general AHP, the following steps were applied using "PopTools" (Hood, 2009) to build a decision-making model - according to Figure 2 - for CT in supply chains.

\section{Step I-CT problem structuring and model construction}

As suggested by Saaty and Vargas (2001), this first step is the most creative (and arguably the most critical) when designing the decision model. To study CT in supply chains, this paper bases the problem structure on the suggested CT typology, the SDAs, and a range of specific business objectives. AHP provides a methodology to synthesize the typology, the decision areas and the business objectives. Following the research objectives, the key question the AHP has to address from the perspective of a firm is: What CT strategy fits best my SCM goals?

Based on ROA as a fundamental business driver, four SDAs were identified. In the AHP, these decision areas form the first layer of criteria. Given a specific situation, a management team needs to prioritize how the profitability of the business should be enhanced. A comparison of the SDAs with regard to their importance to the overall strategy is feasible. The literature review identified three major business objectives in each of the SDAs. These objectives form a layer of sub-criteria in the AHP. Within one decision area, the AHP allows a decision maker to characterize the relative importance of each of the three business objectives. Ultimately, the AHP builds upon a choice of strategic alternatives. The typology of CT deals from a network theory perspective suggests three basic deal structures. These alternatives build the foundation of the AHP for CT in supply chains. Applied to a particular case, each deal structure bears specific advantages and disadvantages with regard to each business objective.

\section{Step II - Pairwise comparison matrices and priority vectors}

The second step is to construct the matrices for pairwise comparisons on the level of SDAs, business objectives, and alternatives. After the construction of the matrices on each level, the model is ready for the input of pairwise comparisons based on the fundamental priority scale. A further activity entails the calculation of local priority vectors and the evaluation of the matrix consistency:

- On the level of strategic decision areas, the SDAs are compared with regard to their influence on the overall goal (see Table 1).

- On the level of business objectives, the objectives within each SDA are compared with regard to their influence on the SDA (see Table 2).

- Finally, the three CT alternatives are compared with regard to their influence on a specific business objective (see Table 3).

\section{Step III - Calculation of priorities of CT alternatives}

The next step is to synthesize all priorities to obtain the global priority of each alternative. First, the global priorities of criteria are calculated, by multiplying the priorities of higher level criteria with the priorities of lower ones. The signifier 
Table 1. Weighting the strategic decision areas (SDA) with regard to their influence on the countertrade strategy decision.

\begin{tabular}{|c|c|c|c|c|c|}
\hline \multicolumn{7}{|c|}{$\begin{array}{c}\text { SDA level: What is the relative importance of SDA ... as compared to SDA... } \\
\text { when influencing the decision of what countertrade strategy to choose? }\end{array}$} \\
\hline $\begin{array}{c}\text { Strategic decision area } \\
\text { (SDA) }\end{array}$ & $\begin{array}{c}\ldots \text { than } \\
\text { M\&S }\end{array}$ & $\begin{array}{c}\ldots \text { than } \\
\text { NRM }\end{array}$ & $\begin{array}{c}\text {..than } \\
\text { T\&I }\end{array}$ & $\begin{array}{c}\ldots \text { than } \\
\text { SCO }\end{array}$ & Priority \\
\hline Marketing \& sales (M\&S) is... & $\mathbf{1}$ & 3.00 & 2.00 & 5.00 & 0.47 \\
\hline Network relationships (NRM) is... & 0.33 & $\mathbf{1}$ & 0.33 & 2.00 & 0.14 \\
\hline Technology \& innovation (T\&I) is... & 0.50 & 3.00 & $\mathbf{1}$ & 3.00 & 0.30 \\
\hline Supply chain operations (SCO) is... & 0.20 & 0.50 & 0.33 & $\mathbf{1}$ & 0.09 \\
\hline
\end{tabular}

$\lambda_{\max }=4.06$, Consistency Ratio (C.R.) $=0.024$

Table 2. Weighting the objectives within a strategy decision area with regard to their influence on the strategic decision area (exemplified by T\&I).

\begin{tabular}{|c|c|c|c|c|}
\hline \multicolumn{6}{|c|}{ Objectives level: What is the relative importance of objective ... } \\
as compared to objective ... when influencing "technology \& innovation" (T\&I)? \\
\hline Technology \& innovation & $\ldots$ than TA & $\ldots$ than QC & $\ldots$ than IPP & Priority \\
\hline Technology access (TA) is... & $\mathbf{1}$ & 0.25 & 0.50 & 0.14 \\
\hline Quality control (QC) is... & 4.00 & $\mathbf{1}$ & 3.00 & 0.63 \\
\hline IP protection (IPP) is... & 2.00 & 0.33 & $\mathbf{1}$ & 0.24 \\
\hline
\end{tabular}

$\lambda_{\max }=3.02$, Consistency Ratio (C.R.) $=0.018$

Table 3. Weighting the different countertrade alternatives with regard to their influence on a specific objective (exemplified by QC).

\begin{tabular}{|c|c|c|c|c|}
\hline \multicolumn{6}{|c|}{$\begin{array}{c}\text { CT alternatives level: What is the relative importance of alternative ... } \\
\text { as compared to alternative ... when influencing quality control (QC)? }\end{array}$} \\
\hline Quality control & $\ldots$ than CA & $\ldots$ than OpBB & $\ldots$ than CIBB & Priority \\
\hline Compensation deals (CA) is... & $\mathbf{1}$ & 0.50 & 0.50 & 0.45 \\
\hline Operating buy-back (OpBB) is... & 2.00 & $\mathbf{1}$ & 0.75 & 0.83 \\
\hline Capital investment buy-back (CiBB) is... & 2.00 & 1.33 & $\mathbf{1}$ & 1.00 \\
\hline
\end{tabular}

$\lambda_{\max }=3.01$, Consistency Ratio (C.R.) $=0.009$

$\mathrm{w}_{\mathrm{j}}$ has been used in literature to denote these composite priorities. Subsequently, the local priorities of each alternative are multiplied by the composite criteria priorities $\left(\mathrm{w}_{\mathrm{j}}\right)$ and added up to obtain the global priority of each alternative. This step contains the synthesis of all local priorities (alternatives, objectives, SDAs) towards a global priority of each alternative.

\section{Step VI-Ranking of CT alternatives}

The global priority of each CT alternative represents its performance given the weighting of SDA's, the importance of each of the business objectives, and the alternative's potential to achieve each objective. A decision-making team can further look into the weights of alternatives, and composite weights of criteria to understand 
the factors that drive the decision and discuss the outcome of the collective decisionmaking process. It is apparent that a valid result is highly dependent on the first step, the problem structuring and model construction. It is of vital importance to include all decision factors as the validity of the outcome depends on a proper foundation of the model.

\section{Practical Illustration}

\section{Backdrop: Automotive Industry in 2010}

The brief case illustration is set in the automotive industry. On the demand side, traditional auto markets have been stagnating while growth has been mainly driven by emerging markets. Competitive pressure remains, and manufacturers face increasing pressure for consolidation as exit barriers are high. Overcapacity in traditional markets increases competition based on cost. In addition, new players from emerging markets take shape and upgrade their technology to tap into the global market. Also from a largely consolidated supplier side, manufacturers are facing increasing pressure and raw material prices are only increasing in the longer term. The automobile industry faces pressure from all sides - to shape and manage supply chain network relationships effectively is more important than ever (Frost and Sullivan, 2009).

\section{Underlying Supply Chain Network}

The OEM considered is a global auto manufacturing conglomerate based in Germany. In its supply chain network, it uses a range of tier-1 suppliers to manufacture specific input materials of which synthetics were one of them. The already highly efficient supply chains demands superior standards in terms of product quality, manufacturing flexibility and dependability, even if lead times were sometimes long. From a range of synthetics suppliers, the OEM chose 15 key subcontractors. The tier-1 supplier in focus has been a supplier of the OEM for several years.

The tier-1 supplier is trying to adopt the high service level standards demanded by its OEM customers. It purchases synthetics pellets from different, large raw materials suppliers on the world market. However, the firm has frequently been challenged by unsteady raw materials supply in quantity and quality, and input price fluctuations (also due to exchange rate fluctuations) vis-à-vis continuous price pressure from OEMs.

The raw materials supplier (tier-2) is a large chemicals company that supplied synthetics to the upstream end of the automobile industry besides other markets.

Could a CT between OEM and tier-1 supplier help both firms to increase supply chain efficiency and enhance competitiveness? And what kind of CT in particular would best fit both the OEM's and the tier-1 supplier's business objectives?

\section{Countertrade Alternatives}

In a CA, the OEM offers coaching services to the tier-1 supplier to increase its procurement capabilities towards the raw materials supplier tier-2 and also improve internal and external supply chain efficiency. In return, the tier-1 supplier offers 
discounts or assigns additional production capacity to the OEM. This set-up reflects a light level of collaboration based on an extension of the network relationship to a reciprocal exchange of secondary services.

In an $\mathrm{OpBB}$, the collaboration is taken one step further. The OEM takes a more active role in synthetics pellets purchasing and takes an intermediary position between tier-1 supplier and the raw materials supplier. As a result, the tier-1 supplier receives the input pellets as arranged by the OEM and forwards the output to the OEM after processing.

Lastly, in an CiBB, the OEM invests into production assets (e.g. molding machines) on site of the tier-1 supplier. In return, the OEM receives synthetic pellets produced on these machines at a discount that pays for the amortization of the machinery, or receive more synthetics at the same price, respectively.

\section{OEM Perspective - AHP Application and Result}

The OEM's key strategic priorities towards its upstream value network are supply chain related, and concern active supplier management and quality control. The AHP model enables to reflect these SDA priorities with high relative weights on SCO, NRS and T\&I. In the SCO area, increasing both flexibility and dependability from supplier side was crucial, besides upholding constant pressure on input cost. Related to NRS was the objective to facilitate collaboration with the tier-1 supplier and also extend bargaining power to achieve favorable conditions, while entering a forward purchase agreement for high-specificity inputs. Lastly, quality control was an important driver in the T\&I sphere. These priorities among others were taken into account on business objectives level in the AHP model.

Comparing the different $\mathrm{CT}$ alternatives with regard to their performance on key business objectives exhibits a high potential for both the operating and capital investment buy-back structures. By installing an OpBB structure, the OEM would be able to increase control over its tier-1 supplier with favorable impact on supply chain resilience, potential input cost reduction, and quality control. A CiBB receives higher scores in particular when it comes to the introduction of new products into the supply chain and aligning incentives.

As shown in Table 4 the AHP model supports the choice of an OpBB structure (priority of 0.490 ), followed by the CiBB (priority of 0.358 ), and lastly the CA (priority of 0.151). In this illustrative application of the AHP model for an OEM, the decisive factors are the strategic priorities on $\mathrm{SCO}$, and QC.

Table 4. AHP result for the OEM.

\begin{tabular}{|c|c|c|c|c|c|c|c|c|c|c|c|c|c|}
\hline & \multicolumn{3}{|c|}{ M\&S } & \multicolumn{3}{|c|}{ NRS } & \multicolumn{3}{|c|}{ T\&I } & \multicolumn{3}{|c|}{$\mathrm{SCO}$} & \multirow{3}{*}{ Priority } \\
\hline $\mathrm{j}$ & VM & $\mathrm{P}$ & NPS & BP & MA & IA & TA & QC & IPP & TCR & ICR & SCR & \\
\hline$w_{j}$ & 0.019 & 0.034 & 0.010 & 0.098 & 0.028 & 0.117 & 0.056 & 0.140 & 0.017 & 0.079 & 0.143 & 0.259 & \\
\hline $\mathrm{CA}$ & 0.163 & 0.143 & 0.109 & 0.114 & 0.250 & \begin{tabular}{|l|}
0.169 \\
\end{tabular} & \begin{tabular}{|l|}
0.122 \\
\end{tabular} & 0.149 & 0.648 & 0.097 & 0.109 & 0.163 & 0.151 \\
\hline OpBB & 0.540 & 0.571 & 0.309 & 0.481 & 0.500 & 0.387 & 0.320 & 0.474 & 0.230 & 0.570 & 0.547 & 0.540 & 0.490 \\
\hline $\mathrm{CiBB}$ & 0.297 & 0.286 & 0.582 & 0.405 & 0.250 & 0.443 & 0.558 & 0.376 & 0.122 & 0.333 & 0.345 & 0.297 & 0.358 \\
\hline
\end{tabular}


Table 5. AHP result for the Tier-1 supplier.

\begin{tabular}{|c|c|c|c|c|c|c|c|c|c|c|c|c|c|}
\hline & \multicolumn{3}{|c|}{$M \& S$} & \multicolumn{3}{|c|}{ NRS } & \multicolumn{3}{|c|}{ T\&I } & \multicolumn{3}{|c|}{$\mathrm{SCO}$} & \multirow{3}{*}{ Priority } \\
\hline $\mathrm{j}$ & $\mathrm{VM}$ & $\mathrm{P}$ & NPS & BP & MA & IA & TA & QC & IPP & TCR & ICR & SCR & \\
\hline $\mathrm{w}_{\mathrm{j}}$ & 0.089 & 0.096 & 0.021 & 0.041 & 0.075 & 0.023 & 0.105 & 0.097 & 0.023 & 0.090 & 0.104 & 0.237 & \\
\hline $\mathrm{CA}$ & 0.122 & 0.540 & 0.117 & 0.100 & 0.163 & 0.122 & 0.128 & 0.126 & 0.648 & 0.226 & 0.208 & 0.128 & 0.197 \\
\hline OpBB & 0.320 & 0.163 & 0.268 & 0.433 & 0.297 & 0.320 & 0.276 & 0.458 & 0.122 & 0.674 & 0.661 & 0.595 & 0.444 \\
\hline CiBB & 0.558 & 0.297 & 0.614 & 0.466 & 0.540 & 0.558 & 0.595 & 0.416 & 0.230 & 0.101 & 0.131 & 0.276 & 0.359 \\
\hline
\end{tabular}

\section{Supplier Perspective - AHP Application and Result}

The areas of SCO, T\&I, and M\&S receive high priority weights from the perspective of the supplier. Driven by costly input price fluctuations and a need for currency hedging, the two business objectives SCR and ICR are major factors within SCO. Within T\&I, QR and the possibility to TA are important objectives. Finally, the supplier's decision is also driven by the business need to increase volumes while keeping sales prices stable. The AHP model has been used to take these business objectives among others into account.

When comparing the composite priority weights as well as the performance of the alternatives on the business objectives level, the OpBB structure achieves highest weights in the SCO objectives, as well as in QC. The high relative performance of the OpBB is mostly due to the potential for savings on the OPEX side in the low-margin, high volume raw materials business, the strong input-output quality relationship, and the importance of SCR. However, the CiBB agreement receives higher weights along all other business objectives. In particular, the tier-1 supplier looses less discretion with regard to pricing and is better able to develop its technological capabilities as compared to an OpBB.

The AHP model supports - as Table 5 shows - an OpBB structure (priority of 0.444 ), followed by the CiBB (priority of 0.359 ), and the CA (priority of 0.197 ).

\section{Interpretation of Practical Illustration}

In this illustrative example in the automotive industry, an OpBB structure has been found to fit both an OEM's and a tier-1 supplier's strategic priorities and underlying business objectives. In practice, such a multilateral OpBBis applied successfully by automobile manufacturers [4]. Variations of the second-ranked CiBB is also found in practice (e.g. taper integration by Harrigan,1984 orasset transfer by Wouters, 2006) and bears its own advantages as demonstrated by the AHP. Details of the AHP from the supplier's perspective are illustrated in Appendix 3.

\section{Conclusion}

\section{Discussion}

The contributions of this research from an academic perspective are a conceptualization of the phenomenon of CT as well as steps toward explaining its existence in supply chains and applications of specific forms. With regard to the $R Q 1$, the network perspective has been identified as an appropriate lens to study the reciprocal 
relationships that $\mathrm{CT}$ builds upon. Generic types of CT were identified from a theoretical perspective to define its variants as a suggestion to the field of SCM research. The literature review built a basis to explain the existence of the phenomenon in practice and contributed a range of motivations and drivers of supply chain actors to participate in $\mathrm{CT}(R Q 2)$. These motivations and drivers were distilled and synthesized in a multiplecriteria decision making model to further specify an extensive, yet succinct set of major business objectives. The resulting list of business objectives to $\mathrm{CT}$ is a contribution to further research in $\mathrm{CT}$ and contributes to the discussion of reciprocal arrangements in supply chains, in general. The decision model based on AHP has been used to shed light into the drivers behind a specific form of $\mathrm{CT}$, addressing $R Q 3$. The application of the model demonstrated how specific motivations of an actor influence the choice, and hence, the existence of a specific form of CT in supply chains. In addition, the AHP application also illustrated how external factors could influence the form of the phenomenon in a specific supply chain structure.

The contributions of this research in light of practice are a specification of CT in supply chains and steps towards explaining why firms use specific forms of CT and how they choose what specific form of CT to apply. Different specific forms of CT have been illustrated in various industries and cases demonstrated the range of its applications. The literature review has been structured along SDAs based on ROA as a fundamental driver of business success. The identification and synthesis of a set of specific objectives that relate to the decision areas and that firms pursue in CT contributes to the understanding of the range of factors that $\mathrm{CT}$ affects in practice. Furthermore, the developed AHP model represents a tool that facilitates individual and group decision making with regard to CT in supply chains. It suggests a range of business objectives in SDAs that affect a firm's choice of a specific CT strategy and is extendable on business objectives and CT alternatives level for customized use.

Limitations to the findings of this study from an academic perspective include the following. The focus on network perspective $v s$. an application of several theoretical lenses limits a comparative analysis of the conceptual model. Theories from the field of strategic alliances (e.g. extend production economics theory) are suggested as other, potentially powerful lenses to conceptualize the phenomenon of CT. In addition, several specific limitations to the application of the model have been outlined following the illustrative case. In particular, the identified decision factors need further evaluation and refinement. The structure of the SDAs could provide a frame for further in-depth studies. The interpretation of findings from the case analysis is limited due to the illustrative nature of the case.

From a practice perspective, limitations to the findings of the study are the following. First, potential practical hurdles to CT from a legal perspective (incl. taxes and tariffs) as well as a discussion of effects under (different) accounting standards have not been discussed directly. Second, the study did not quantify the financial impact of different CT agreements on ROA. These are important issues that future studies need to address (e.g. recent studies in these fields include Sumer and Chuah (2007) for legal challenges; and Wouters (2006) as well as Hofmann (2011) for financial effects in reciprocal trades). Third, the paper did not address the process of how firms create a CT agreement and what factors influence the scope, choice of a partner, its development over time, and what factors have led to failures in the past. 
Finally, the general challenge of so called "rank reversal problems" in AHPbased choice has to be addressed. A potential alternative is the "Analytic Network Process" (ANP). The ANP is holistic approach that uses a set of axioms and a variety of factors which are laid out in a hierarchy or in the ANP methodology in a network. There are decision problems which cannot be broken down into hierarchies because they involve interactions between elements on different levels. A linear top down structure like a hierarchy will not work out in case of dependences of higher-level elements on lower-level elements. In this case a network can be used as it spreads out in all directions (Zhu et al., 2010; Tseng et al., 2009; Wu et al., 2009; Mendoza, 2007).

These limitations in addition to the need for further testing and evaluation of the decision model by supply chain professionals give rise to a number of suggestions for further studies.

\section{Outlook}

While research in $\mathrm{CT}$ has been limited in the recent past, practice has reinvented the use of reciprocal deals to structure SCM. This exploratory research helps to close this gap and to both advance theory on the current use of CT as well as to inform practice on the range of objectives a CT might help to achieve.

To advance the theoretical foundation on CT in supply chains today, a research focus in two areas is recommended. First, further conceptualization work is needed to re-invent the current form of CT and to define and delimit the phenomenon from different perspectives. Theories that were used to study strategic alliances as well as foundations of SCM are suggested approaches, while the capability to account for interdependency in a network structure is a critical prerequisite. Second, and directly extending on this research, more in-depth case studies on CT in supply chains in different industries are needed to refine the constructs and gather more illustrations of current best practices and deal drivers. These case studies will also shed light into current legal and regulatory challenges to $\mathrm{CT}$ and help to quantify the profitability impact on business level.

Practitioners should consider the use of CT in their supply chain networks. Interdependency is a fact - countertrade is one way to proactively structure a supply chain relationship to not only acknowledge, but also leverage reciprocity. An integrative approach is critical in a time when long-term business success depends less on an individual firm and more on the supply chain as a whole.

\section{References}

Bahinipati, B.; Kanda, A. and Deshmukh, S.G. (2009) Horizontal collaboration in semiconductor manufacturing industry supply chain: An evaluation of collaboration intensity index. Computers \& Industrial Engineering, Vol. 57, No. 3, pp. 880-895. http://dx.doi. org/10.1016/j.cie.2009.03.003

Baramichai M.; Zimmers Junior, E.W. and Marangos, C.A. (2007) Agile supply chain transformation matrix: an integrated tool for creating an agile enterprise. Supply Chain Management, Vol. 12, No. 5, pp. 334-348. http://dx.doi.org/10.1108/13598540710776917

Baramichai, M. (2007) Supplier partnership establishment under uncertainties for agile organizations. Dissertation. Lehigh University, United States, Pennsylvania. 
Baranowska-Prokop, E. (2009) Direct offsets in international trade as a remedy for asymmetric information. Journal of International Trade Law and Policy, Vol. 8, No. 3, pp. 202212. http://dx.doi.org/10.1108/14770020910990614

Berrah, L. and Clivillé, V. (2007) Towards an aggregation performance measurement system model in a supply chain context. Computers in Industry, Vol. 58, No. 7, pp. 709-719. http://dx.doi.org/10.1016/j.compind.2007.05.012

Berry, D. and Naim, M.M. (1996) Quantifying the relative improvements of redesign strategies in a PC supply chain. International Journal of Production Economics, Vol. 46-47, pp. 181-196. http://dx.doi.org/10.1016/0925-5273(95)00181-6

Bhagwat, R. and Sharma, M. (2007a) An integrated BSC-AHP approach for supply chain management evaluation. Measuring Business Excellence, Vol. 11, No. 3, pp. 57-68. http:// dx.doi.org/10.1108/13683040710820755

Bhagwat, R. and Sharma, M. (2007b) Performance measurement of supply chain management using the analytical hierarchy process. Production Planning \& Control, Vol. 18, No. 8, pp. 666-680. http://dx.doi.org/10.1080/09537280701614407

Bhagwat, R. and Sharma, M. (2009) An application of the integrated AHP-PGP model for performance measurement of supply chain management. Production Planning \& Control, Vol. 20, No. 8, pp. 678-690. http://dx.doi.org/10.1080/09537280903069897

Boardman, L.; Liu, L.B.; Berger, P.; Zeng, A. and Gerstenfeld, A. (2008) Applying the analytic hierarchy process to the offshore outsourcing location decision. Supply Chain Management, Vol. 13, No. 6, pp. 435-449. http://dx.doi.org/10.1108/13598540810905697

Brintrup, A. (2010) Behaviour adaptation in the multi-agent, multi-objective and multi-role supply chain. Computers in Industry, Vol. 61, No. 7, pp. 636-645. http://dx.doi. org/10.1016/j.compind.2010.03.010

Cao, N. (2006) Supply chain performance measurement in textile and apparel industries. Dissertation. Hong Kong Polytechnic University, Hong Kong.

Chan, F.; Chan, H.K.; Ip, R.W.L. and Lau, H.C.W. (2007a) A decision support system for supplier selection in the airline industry. Proceedings of the Institution of Mechanical Engineers, Part B, Engineering Manufacture, Vol. 221 No. 4, pp. 741-758.

Chan, F.; Kumar, N. and Choy, K.L. (2007b) Decision-making approach for the distribution centre location problem in a supply chain network using the fuzzy-based hierarchical concept. Proceedings of the Institution of Mechanical Engineers, Part B, Engineering Manufacture, Vol. 221, No. 4, pp. 725-739.

Chan, F.; Kumar, N.; Tiwari, M.K.; Lau, H.C.W. and Choy, K.L. (2008) Global supplier selection: a fuzzy-AHP approach. International Journal of Production Research, Vol. 46, No.14, pp. 3825-3857. http://dx.doi.org/10.1080/00207540600787200

Che, Z. (2010) Using fuzzy analytic hierarchy process and particle swarm optimisation for balanced and defective supply chain problems considering WEEE/RoHS directives. International Journal of Production Research, Vol. 48, No. 11, pp. 3355-3381. http:// dx.doi.org/10.1080/00207540802702080

Chen, S. and $\mathrm{Wu}, \mathrm{W}$. (2010) A systematic procedure to evaluate an automobile manufacturer-distributor partnership. European Journal of Operational Research, Vol. 205, No. 3, pp. 687-698. http://dx.doi.org/10.1016/j.ejor.2010.01.036

Chen, Y. and Huang, P. (2007) Bi-negotiation integrated AHP in suppliers selection. Benchmarking, Vol. 14, No. 5, pp. 575-593. http://dx.doi.org/10.1108/14635770710819263

Choi, C.J.; Lee, S.H. and Kim, J.B. (1999) A Note on Countertrade: Contractual Uncertainty and Transaction Governance in Emerging Economies. Journal of International Business Studies, Vol. 39, No. 1, pp. 189-201. http://dx.doi.org/10.1057/palgrave.jibs.8490066 
Choi, S.-R. andTschoegl, A.E. (2003) Currency risks, government procurement and counter-trade: A note. Applied Financial Economics, Vol. 13, pp. 885-889. http://dx.doi. org/10.1080/0960310032000129644

Drzymalski, J. (2008) A synchronized supply chain for a multi-echelon, multi-stage system. Dissertation. Lehigh University, United States - Pennsylvania.

Enyinda, C. (2009) Modeling risk management in the pharmaceutical industry global supply chain logistics using analytic hierarchy process model. Dissertation, North Dakota State University, United States, North Dakota.

Fletcher, R. (1996) Network Theory and Countertrade Transaction. International Business Review, Vol. 5, No. 2, pp. 167-189. http://dx.doi.org/10.1016/0969-5931(96)00004-2

Fletcher, R. (2009) Countertrade and International Outsourcing: A Relationship and Network Perspective. International University of Geneva (IUG) Business Review, pp. 25-42.

Forker, L.B. (1996) Countertrade's Impact on the Supply Function. International Journal of Purchasing and Materials Management, Fall, pp. 37-45.

Forker, L.B. (1997) Internationalizing Procurement: Determinants of Countertrade Involvement. International Journal of Purchasing and Materials Management, Spring, pp. 27-34.

Frost \& Sullivan (2009) Global Automotive Industry Outlook 2009: Impact of Economic Slowdown on the Future of Auto Sales and Production. London: Frost \& Sullivan.

Gaudenzi B. and Borghesi A. (2006) Managing risks in the supply chain using the AHP method. International Journal of Logistics Management, Vol. 17, No. 1, pp. 114-136. http:// dx.doi.org/10.1108/09574090610663464

Gnanasekaran S.; Selladurai, V. and Manimaran, P. (2006) Application of Analytical Hierarchy Process in Supplier Selection: An Automobile Industry Case Study. South Asian Journal of Management, Vol. 13, No. 4, pp. 89-100.

Göl, H. and Çatay, B. (2007) Third-party logistics provider selection: insights from a Turkish automotive company. Supply Chain Management, Vol. 12, No. 6, pp. 379-384. http:// dx.doi.org/10.1108/13598540710826290

Håkansson, H. and Persson, G. (2004) Supply Chain Management: The Logic of Supply Chains and Networks. International Journal of Logistics Mangement, Vol. 15, No. 1, pp. 11-26. http://dx.doi.org/10.1108/09574090410700202

Haq, A. and Kannan, G. (2007) A hybrid normalised multi criteria decision making for the vendor selection in a supply chain model. International Journal of Management \& Decision Making, Vol. 8, No. 5-6, pp. 601-622. http://dx.doi.org/10.1504/IJMDM.2007.013421

Harrigan, K.R. (1984) Formulating Vertical Integration Strategies. Academy of Management Review, Vol. 9, No. 4, pp. 638-652.

Hennart, J.-F. (1990) Some Empirical Dimensions of Countertrade. Journal of International Business Studies, Vol. 21, No. 2, pp. 243-270. http://dx.doi.org/10.1057/palgrave. jibs. 8490334

Hennart, J.-F. and Anderson, E. (1993) Countertrade and the Minimization of Transaction Costs: An Empirical Examination. Journal of Law, Economics \& Organization, Vol. 9, No. 2, pp. 290-313.

Ho, W.; Lee, C.K.M. and Ho, G.T.S. (2010) Multiple criteria optimization of contemporary logistics distribution network problems. OR Insight, Vol. 23, No. 1, pp. 27-43. http://dx.doi.org/10.1057/ori.2009.7

Hofmann, E. (2011) Natural hedging as a risk prophylaxis and supplier financing instrument in automotive supply chains. Supply Chain Management: An International Journal, Vol. 16, No. 2, pp. 128-141. http://dx.doi.org/10.1108/13598541111115374 
Hood, G.M. (2009) PopTools Version 3.1. PopTools. Available: http://www.poptools. org. Access: 10th May, 2010.

Hult, G.T.; Ketchen, D.J. and Arrfelt, M. (2007) Strategic Supply Chain Management: Improving perfor-mance through a culture of competitiveness and knowledge development. Strategic Management Journal, Vol. 28, pp. 1035-1052. http://dx.doi.org/10.1002/smj.627

Kanda, A. and Deshmukh, S. (2007) Coordination in supply chains: an evaluation using fuzzy logic. Production Planning \& Control, Vol. 18, No. 5, pp. 420-435. http://dx.doi. org/10.1080/09537280701430994

Kannan, G. (2009) Fuzzy approach for the selection of third party reverse logistics provider. Asia Pacific Journal of Marketing and Logistics, Vol. 21, No. 3, pp. 397-416. http:// dx.doi.org/10.1108/13555850910973865

Kannan, G.; Haq, A.N. and Sasikumar, P. (2008a) An application of the Analytical Hierarchy Process and Fuzzy Analytical Hierarchy Process in the selection of collecting centre location for the reverse logistics Multicriteria Decision-Making supply chain model. International Journal of Management \& Decision Making, Vol. 9, No. 4, pp. 350-365. http://dx.doi.org/10.1504/ IJMDM.2008.019360

Kannan, G.; Haq, A.N.; Sasikumar, P. and Arunachalam, S. (2008b) Analysis and selection of green suppliers using interpretative structural modelling and analytic hierarchy process. International Journal of Management \& Decision Making, Vol. 9, No. 2, pp. 163-182. http://dx.doi.org/10.1504/IJMDM.2008.017198

Kannan, G.; Murugesan, P. and Haq, A.N. (2009) 3PRLP's selection using an integrated analytic hierarchy process and linear programming. International Journal of Services Technology and Management, Vol. 12, No. 1, pp. 61. http://dx.doi.org/10.1504/ IJSTM.2009.025036

Kengpol, A. (2008) Design of a decision support system to evaluate logistics distribution network in Greater Mekong Subregion Countries. International Journal of Production Economics, Vol. 115, No.2, pp. 388-399. http://dx.doi.org/10.1016/j.ijpe.2007.10.025

Khoury, S.J. (1984) Countertrade: Forms, Motives, Pitfalls, and Negotiation Requisites. Journal of Business Research, Vol. 12, pp. 257-270. http://dx.doi.org/10.1016/01482963(84)90010-9

King, A.M. and Sivaloganathan, S. (1999) Development of a Methodology for Concept Selection in Flexible Design Strategies. Journal of Engineering Design, Vol. 10, No. 4, pp. 329-349. http://dx.doi.org/10.1080/095448299261236

Kinra, A. and Kotzab, H. (2008) Understanding and measuring macro-institutional complexity of logistics systems enviroment. Journal of Business Logistics, Vol. 29, No.1, pp. $327-$ 346. http://dx.doi.org/10.1002/j.2158-1592.2008.tb00082.x

Kodali, R. and Routroy, S. (2006) Decision framework for selection of facilities location in competitive supply chain. Journal of Advanced Manufacturing Systems, Vol. 5, No.1, pp. 89-110. http://dx.doi.org/10.1142/S021968670600073X

Kuei, C.; Madu, C.N. and Lin C. (2008) Implementing supply chain quality management. Total Quality Management \& Business Excellence, Vol. 19, No. 11, pp. 1127-1142. PMCid:2860396. http://dx.doi.org/10.1080/14783360802323511

Kull, T. and Talluri, S. (2008) A Supply Risk Reduction Model Using Integrated Multicriteria Decision Making. IEEE Transactions on Engineering Management, Vol. 55, No. 3, pp. 409-419. http://dx.doi.org/10.1109/TEM.2008.922627

Kumar, S. and Bisson, J. (2008) Utilizing analytic hierarchy process for improved decision making within supply chains. Human Systems Management, Vol. 27, No. 1, pp. 49-62. 
Kuo, R.; Lee, L.Y. and Hu, T.-L. (2010) Developing a supplier selection system through integrating fuzzy AHP and fuzzy DEA: a case study on an auto lighting system company in Taiwan. Production Planning \& Control, Vol. 21, No. 5, pp. 468-484. http://dx.doi. org/10.1080/09537280903458348

Kuo, R.; Wang, Y.C. and Tien, F.C. (2010) Integration of artificial neural network and MADA methods for green supplier selection. Journal of Cleaner Production, Vol. 18, No. 12 , pp 1161-1170. http://dx.doi.org/10.1016/j.jclepro.2010.03.020

Lecraw, D.J. (1989) The Management of Countertrade: Factors Influencing Success. Journal of International Business Studies, Vol. 20, No. 1, pp. 41-59. http://dx.doi.org/10.1057/ palgrave.jibs. 8490350

Levary, R. (2007) Ranking foreign suppliers based on supply risk. Supply Chain Management, Vol. 12, No. 6, pp. 392-394. http://dx.doi.org/10.1108/13598540710826317

Levary, R. (2008) Using the analytic hierarchy process to rank foreign suppliers based on supply risks. Computers \& Industrial Engineering, Vol. 55, No. 2, pp. 535-542. http:// dx.doi.org/10.1016/j.cie.2008.01.010

Ligi, A. and Kolesnikova, M. (2009) Crops-for-Chemicals barter gives farmers liquidity.Bloomberg. Available: http://www.bloomberg.com/apps/news?pid=20601109\&sid=a 2wmOBBYHDBY. Access: 7th June, 2010.

Liu, L.; Liu, L.B.; Berger, P.; Zeng, A. and Gerstenfeld, A. (2008) Applying the analytic hierarchy process to the offshore outsourcing location decision. Supply Chain Management, Vol. 13, No. 6, pp. 435-449. http://dx.doi.org/10.1108/13598540810905697

Lorentz, H. (2008) Production locations for the internationalising food industry: case study from Russia. British Food Journal, Vol. 110, No. 3, pp. 310-334. http://dx.doi. org/10.1108/00070700810858718

Lu, L.; Wua, C.H. and Kuo, T.-C. (2007) Environmental principles applicable to green supplier evaluation by using multi-objective decision analysis. International Journal of Production Research, Vol. 45, No. 18-19, pp. 4317-4331. http://dx.doi.org/10.1080/00207540701472694

Mendoza, A. (2007) Effective methodologies for supplier selection and order quantity allocation. Dissertation. The Pennsylvania State University, United States, Pennsylvania.

Mirus, R. and Yeung, B. (2001)The Economics of Barter and Countertrade. Cheltenham: Elgar.

Naesens, K.; Naesens, K.; Gelders, L. and Pintelon, L. (2007) A swift response tool for measuring the strategic fit for resource pooling: a case study. Management Decision, Vol. 45, No. 3, pp. 434-449. http://dx.doi.org/10.1108/00251740710745061

Neale, C.W. and Sercu, P. (1993) Countertrade in International and Domestic Markets. The International Trade Journal, Vol. 7, No. 3, pp. 271-294. http://dx.doi. org/10.1080/08853909308523766

Palliam, R. (2005) Application of a multi-criteria model for determining risk premium. The Journal of Risk Finance, Vol. 6, No. 4, pp. 341-348. http://dx.doi. org/10.1108/15265940510613679

Parthiban, P.; Punniyamoorthy, M.; Ganesh, K.; Parthasarathi, N.L. and Arunachalam, S. (2008) Logical approach for evaluation of supply chain alternatives. International Journal of Management \& Decision Making, Vol. 9, No. 2, pp. 204-223. http://dx.doi.org/10.1504/ IJMDM.2008.017200

Paun, D.A. (1997) An International Profile of Countertrading Firms. Industrial Marketing Management, Vol. 26, pp. 41-50. http://dx.doi.org/10.1016/S0019-8501(96)00030-2

Paun, D.A. and Shoham, A. (1996) Marketing Motives in International Countertrade: An Empirical Examination. Journal of International Marketing, Vol. 4, No. 3, pp. 29-47. 
Paun, D.A.; Compeau, L.D. and Grewal, D. (1997) A Model of the Influence of Marketing Objectives on Pricing Strategies in International Countertrade. Journal of Public Policy \& Marketing, Vol. 16, No. 1, pp. 69-82.

Rabelo, L.; Eskandari, H.; Shaalan, T. and Helal, M. (2007) Value chain analysis using hybrid simulation and AHP. International Journal of Production Economics, Vol. 105, No. 2, pp. 536-547. http://dx.doi.org/10.1016/j.ijpe.2006.05.011

Ramanathan, R. (2007) Supplier selection problem: integrating DEA with the approaches of total cost of ownership and AHP. Supply Chain Management, Vol. 12, No. 4, pp. 258-261. http://dx.doi.org/10.1108/13598540710759772

Rao, R. and Patel, B. (2010) Decision making in the manufacturing environment using an improved PROMETHEE method. International Journal of Production Research, Vol. 48, No. 16, pp. 4665-4682. http://dx.doi.org/10.1080/00207540903049415

Reisman, A.; Fuh, D.-C. and Li, G. (1988) Achieving an Advantage with Countertrade. Industrial Marketing Management, Vol. 17, pp. 44-63. http://dx.doi.org/10.1016/00198501(88)90027-2

Routroy, S. (2009) Selection of Third Party Logistics Provider in supply chain. International Journal of Services Technology and Management, Vol. 12, No. 1, pp. 23-24. http:// dx.doi.org/10.1504/IJSTM.2009.025034

Saaty, T.L. (1980) The Analytic Hierarchy Process. New York: McGraw-Hill.

Saaty, T.L. and Vargas, L.G. (2001) Models, Methods, Concepts \& Applications of the Analytic Hierarchy Process. Norwell: Kluwer Academic Publishers.

Saaty, T.L. and Vargas, L.G. (2006) Decision Making with the Analytic Network Process. New York: Springer.

Samiee, S. (2003) International Counter-trade: A Reverse Marketing Perspective. Advances in International Marketing, Vol. 14, pp. 9-33. http://dx.doi.org/10.1016/S14747979(03)14002-1

Sarker, R. and Zahir, S. (2008) Supply Chain Expansion Using AHP, ILP and Scenario-Planning. Journal of American Academy of Business, Vol. 14, No.1, pp. 21-29.

Sarmiento R. and Thomas, A. (2010) Identifying improvement areas when implementing green initiatives using a multitier AHP approach. Benchmarking, Vol. 17, No. 3 , pp. $452-463$.

Schoenherr, T.; Tummalaa, V.M.R. and Harrison, T.P. (2008) Assessing supply chain risks with the analytic hierarchy process: Providing decision support for the offshoring decision by a US manufacturing company. Journal of Purchasing \& Supply Management, Vol. 14, No. 2, pp. 100-111. http://dx.doi.org/10.1016/j.pursup.2008.01.008

Selçuk P. (2008) Use of fuzzy AHP for evaluating the benefits of information-sharing decisions in a supply chain. Journal of Enterprise Information Management, Vol. 21, No. 3, pp. 263-284. http://dx.doi.org/10.1108/17410390810866637

Sen, C.; Şen, S. and Başligil, H. (2010) Pre-selection of suppliers through an integrated fuzzy analytic hierarchy process and max-min methodology. International Journal of Production Research, Vol. 48, No. 6, pp. 1603-1625. http://dx.doi.org/10.1080/00207540802577946

Sevkli, M.; Koh, S.C.L.; Zaim, S.; Demirbag, M. and Tatoglu, E. (2007). An application of data envelopment analytic hierarchy process for supplier selection: a case study of BEKO in Turkey. International Journal of Production Research, Vol. 45, No. 9, pp. 1973-2003. http://dx.doi.org/10.1080/00207540600957399

Sevkli, M.; Sevkli, M.; Koh, S.C.L.; Zaim, S.; Demirbag, M. and Tatoglu, E. (2008) Hybrid analytical hierarchy process model for supplier selection. Industrial Management \& Data Systems, Vol. 108, No. 1, pp. 122-142. http://dx.doi.org/10.1108/02635570810844124 
Sha D.Y. and Che Z.H. (2006) Supply chain network design: partner selection and production/distribution planning using a systematic model. Journal of the Operational Research Society, Vol. 57, No.1, pp. 52-62. http://dx.doi.org/10.1057/palgrave.jors.2601949

Sherwat, E. (2010) An alternative methodology for formulating an operations strategy: the case of BTC-Egypt. Management Decision, Vol. 48, No. 6, pp. 868-893. http:// dx.doi.org/10.1108/00251741011053442

Sheu, J. (2008) A hybrid neuro-fuzzy analytical approach to mode choice of global logistics management. European Journal of Operational Research, Vol. 189, No. 3, pp. 971-986. http://dx.doi.org/10.1016/j.ejor.2006.06.082 International.

Slack, N. and Lewis, M. (2008) Operations Strategy. London: Prentice Hall

Stock, J.R.; Boyer, S.L. and Harmon, T. (2010) Research opportunities in supply chain management. Journal of the Academy of Marketing Science, Vol. 38, No. 1, pp. 32-41. http://dx.doi.org/10.1007/s11747-009-0136-2

Sumer, M. and Chuah, J. (2007) Emerging Legal Challenges for Countertrade Techniques in International Trade. International Trade Legal Review, Vol. 13, No. 6, pp. 111-124.

Teague, J. and Eilon, S. (1973) Productivity measurement: a brief survey. Applied Economics, Vol. 5, No. 5, pp. 133-145. http://dx.doi.org/10.1080/00036847300000010

Ting, S. and Cho, D. (2008) An integrated approach for supplier selection and purchasing decisions. Supply Chain Management, Vol. 13, No. 2, pp. 116-127. http://dx.doi. org/10.1108/13598540810860958

Tsai, M.; Liao, C.-H. and Han, C.-S. (2008) Risk perception on logistics outsourcing of retail chains: model development and empirical verification in Taiwan. Supply Chain Management, Vol. 13, No. 6, pp. 415-424. http://dx.doi.org/10.1108/13598540810905679

Tsai, W. and Hung, S. (2009) A fuzzy goal programming approach for green supply chain optimisation under activity-based costing and performance evaluation with a value-chain structure. International Journal of Production Research, Vol. 47, No. 18, pp. 4991-5017. http:// dx.doi.org/10.1080/00207540801932498

Tseng, M.; Chiang, J.H. and Lan, L.W. (2009) Selection of optimal supplier in supply chain management strategy with analytic network process and choquet integral. Computers \& Industrial Engineering, Vol. 57, No. 1, pp. 330-340. http://dx.doi.org/10.1016/j.cie.2008.12.001

Tzong-Ru, L.; Tuan, T.-Y. and Liu, M.-C. (2008) The application of fuzzy analytic hierarchy process for supply chain decision making: a case study of original brand manufacturing of the sewing machine industry in Taiwan. International Journal of Management \& Decision Making, Vol. 9, No. 2, pp. 154-162. http://dx.doi.org/10.1504/IJMDM.2008.017197

Varma, S.; Wadhwa, S. and Deshmukh, S.G. (2008) Evaluating petroleum supply chain performance: Application of analytical hierarchy process to balanced scorecard. Asia Pacific Journal of Marketing and Logistics, Vol. 20, No. 3, pp. 343-356. http://dx.doi. org/10.1108/13555850810890093

Vijayvargiya, A. and Dey, A. (2010) An analytical approach for selection of a logistics provider. Management Decision, Vol. 48, No. 3, pp. 403-418. http://dx.doi. org/10.1108/00251741011037774

Wang, G. (2001) Product-enabled design and evaluation of manufacturing supply chain: An integrated multi-criteria decision-based methodology. Dissertation. The University of Toledo, United States, Ohio.

Wouters, M. (2006) Implementation costs and redistribution mechanisms in the economic evaluation of supply chain management initiatives. Supply Chain Management: An International Journal, Vol. 11, No. 6, pp. 510-521. http://dx.doi.org/10.1108/13598540610703909 
Wu, T.; Blackhurst, J. and Chidambaram, V. (2006) A model for inbound supply risk analysis. Computers in Industry, Vol. 57, No. 4, pp. 350-365.

Wu, C.; Barnes, D.; Rosenberg, D. and Xinxing. (2009). An analytic network process-mixed integer multi-objective programming model for partner selection in agile supply chains. Production Planning \& Control, Vol. 20, No. 3, pp. 254-275. http://dx.doi. org/10.1080/09537280902856047

Yan, W.; Chen, C.-H.; Huang, Y. and Mi, W. (2008) An integration of bidding-oriented product conceptualization and supply chain formation. Computers in Industry, Vol. 59, No. 2-3, pp. 128- 144. http://dx.doi.org/10.1016/j.compind.2007.06.008

Yavas, B.F. and Freed, R. (2001)An Economic Rationale for Countertrade: Liquidity Constraints. The International Trade Journal,Vol. 15, No. 2, pp. 127-155. http://dx.doi. org/10.1080/088539001316901015

Zhu, Q.; Dou, Y. and Sarkis, J. (2010) A portfolio-based analysis for green supplier management using the analytical network process. Supply Chain Management, Vol. 15, No 4, pp. 306-319. http://dx.doi.org/10.1108/13598541011054670

\section{Biography}

Erik Hofmann ("Dr. rer. pol.", University of Technology, Darmstadt, Germany) is vice president of the Chair for Logistics Management (LOG-HSG), an assistant professor at the University of St. Gallen, St. Gallen as well as a visiting professor at Dresden University of Technology, Germany. His primary research focuses on the intersections of logistics and supply chain management on the one side and finance- and performance-issues on the other side. This research stream encompasses performance measurement in supply chains, supply chain finance, mergers \& acquisitions in logistics, and working capital management in supply chains. He has published in several logistics journals (e.g. Production Planning \& Control, International Journal of Physical Distribution \& Logistics Management or International Journal of Operations \& Production Management).

Contact: erik.hofmann@unisg.ch

\section{Article Info:}

Received: September, 2011

Accepted: December, 2011 
Appendix 1. Literature review on countertrade.

The literature review is based on a search for articles in data bases incl. EBSCO, ProQuest, ScienceDirect, Elsevier, JSTOR and Emerald. Key-words used in the search included: countertrade, reciprocal trade, barter, offset, buy-back, vertical integration, investment integration, reciprocity, international trade. Academic and scholarly publications from the area of international trade, international business, international marketing, and supply chain management form the core literature body. In total 20 relevant articles were selected (see Appendix 1).

Appendix 1. Countertrade literature ranked by year and business objective.

\begin{tabular}{|c|c|c|c|c|c|c|c|c|c|c|c|c|c|c|c|c|c|c|c|c|}
\hline 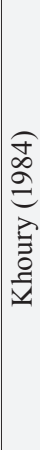 & 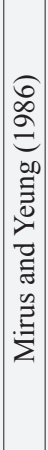 & 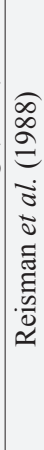 & 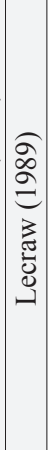 & 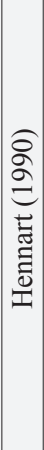 & 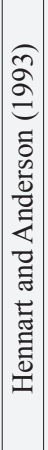 & 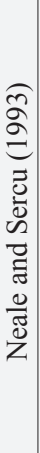 & 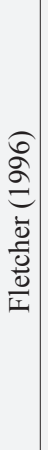 & 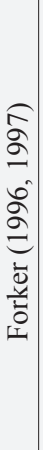 & $\begin{array}{c}\underset{\hat{\sigma}}{\Omega} \\
\underset{\Xi}{\Xi} \\
\Xi \\
\Xi\end{array}$ & 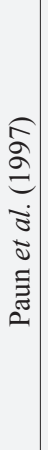 & $\begin{array}{l}\approx \\
\Omega \\
\Omega \\
\check{\Xi} \\
\check{\Xi} \\
\overrightarrow{0} \\
\approx\end{array}$ & 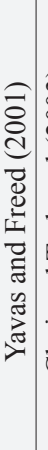 & 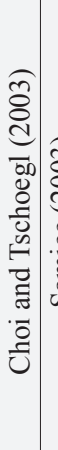 & 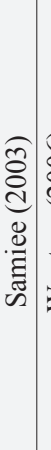 & 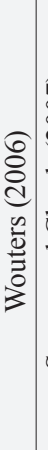 & 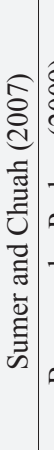 & 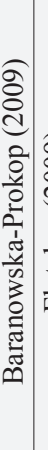 & 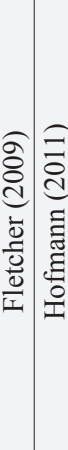 & 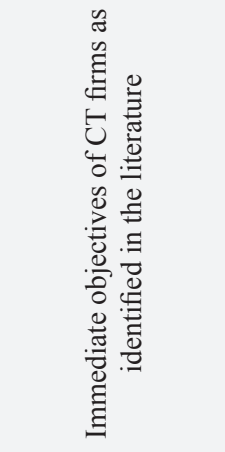 & 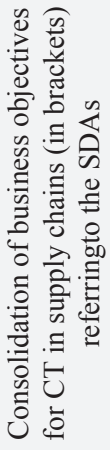 \\
\hline & & & & & & $\mathrm{X}$ & $\mathrm{X}$ & $\mathrm{X}$ & $X$ & $X$ & & & & & & & & & $\begin{array}{c}\text { Increase sales } \\
\text { volume }\end{array}$ & $\begin{array}{l}\text { M\&S } \\
(\mathrm{VM})\end{array}$ \\
\hline & & $X$ & & & & $X$ & & $\mathrm{X}$ & & $X$ & & & & X & & & & & $\begin{array}{l}\text { Market excess } \\
\text { inventory }\end{array}$ & $\begin{array}{l}\text { M\&S } \\
(\mathrm{VM})\end{array}$ \\
\hline & & & & & & $\mathrm{X}$ & & $X$ & & & & & & & & & & & $\begin{array}{l}\text { Dispose declining } \\
\text { products }\end{array}$ & $\begin{array}{l}\text { M\&S } \\
(\mathrm{VM})\end{array}$ \\
\hline & & & & & & & & $X$ & $X$ & $\mathrm{X}$ & & & & & & & & & $\begin{array}{c}\text { Increase sales } \\
\text { price }\end{array}$ & $\begin{array}{c}\mathrm{M} \& \mathrm{~S} \\
(\mathrm{P})\end{array}$ \\
\hline & $\mathrm{X}$ & & & & & & & $X$ & & & & & & X & & & & & $\begin{array}{l}\text { Circumvent } \\
\text { money-price } \\
\text { negotiations }\end{array}$ & $\begin{array}{c}\mathrm{M} \& \mathrm{~S} \\
(\mathrm{P})\end{array}$ \\
\hline & & & $\mathrm{X}$ & & & $\mathrm{X}$ & & & & $X$ & & & & & & & X & & $\begin{array}{l}\text { Provide hidden } \\
\text { discounts }\end{array}$ & $\begin{array}{c}\mathrm{M} \& \mathrm{~S} \\
(\mathrm{P})\end{array}$ \\
\hline & $\mathrm{X}$ & & $\mathrm{X}$ & & & & & & & $X$ & & & & & & & & & $\begin{array}{c}\text { Account for } \\
\text { disequilibrated } \\
\text { exchange rates }\end{array}$ & $\begin{array}{c}M \& S \\
(P)\end{array}$ \\
\hline & $\mathrm{X}$ & $X$ & & & & & & & & & & & & & & & & & Bundle products & $\begin{array}{l}\text { M\&S } \\
\text { (NPS) }\end{array}$ \\
\hline & & X & & & & & X & & & & & & & & & & & & $\begin{array}{l}\text { Introduce new } \\
\text { product }\end{array}$ & $\begin{array}{l}\text { M\&S } \\
\text { (NPS) }\end{array}$ \\
\hline
\end{tabular}

SDA Marketing \& sales, M\&S: Volume management (VM), pricing (P) and new product support (NPS). SDA Network relationships, NRS: Bargaining power (BP), market access (MA) and incentives alignment (IA). SDA Technology \& innovation, T\&I: Technology access (TA), quality control (QC) and intellectual property protection (IPP). SDA Supply chain operations, SCO: Transaction cost reduction (TCO), input cost reduction (ICR) and supply chain resilience (SCR). 
Appendix 1. Continued...

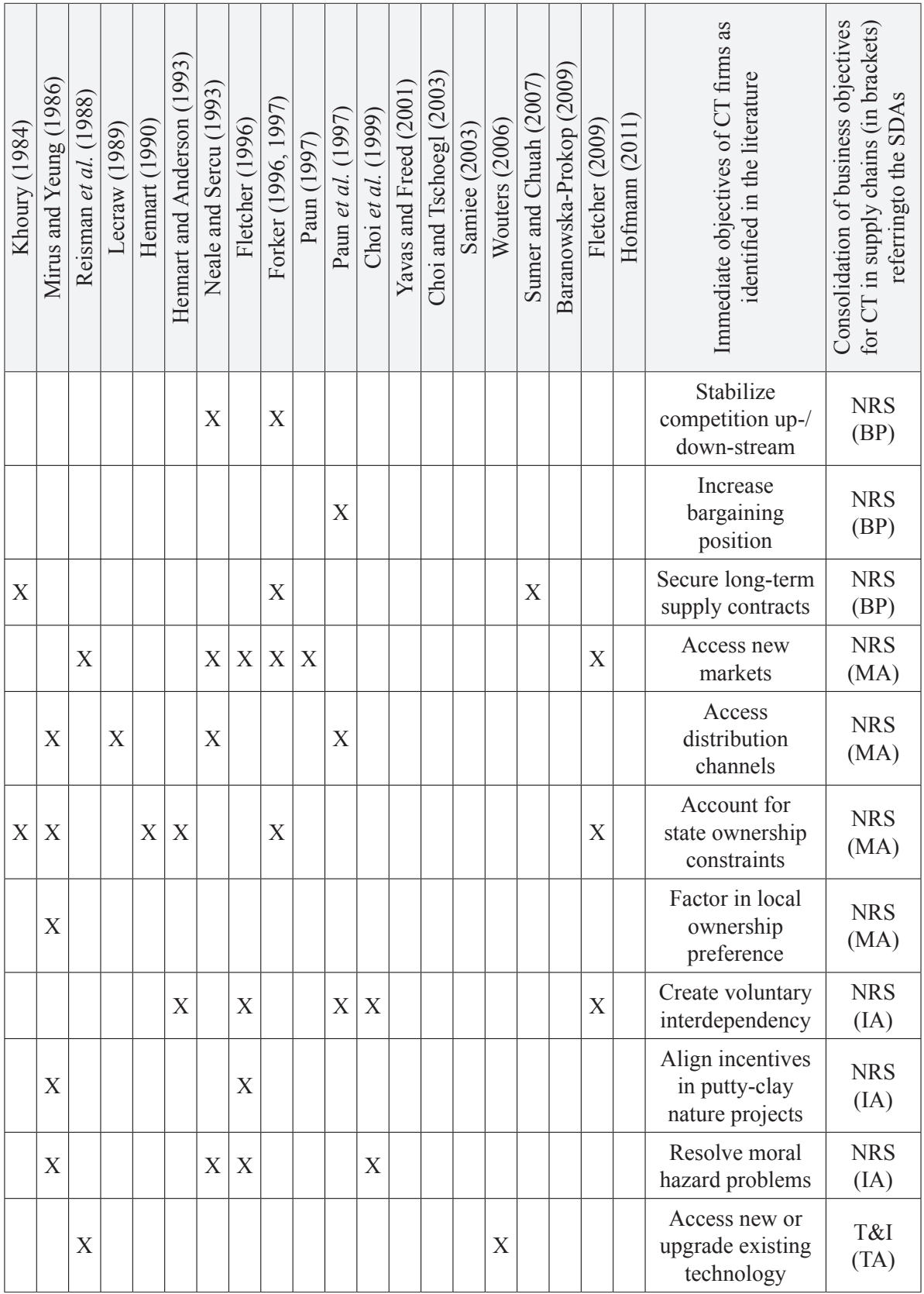

SDA Marketing \& sales, M\&S: Volume management (VM), pricing (P) and new product support (NPS). SDA Network relationships, NRS: Bargaining power (BP), market access (MA) and incentives alignment (IA). SDA Technology \& innovation, $T \& I$ : Technology access (TA), quality control (QC) and intellectual property protection (IPP). SDA Supply chain operations, SCO: Transaction cost reduction (TCO), input cost reduction (ICR) and supply chain resilience (SCR). 
Appendix 1. Continued...

\begin{tabular}{|c|c|c|c|c|c|c|c|c|c|c|c|c|c|c|c|c|c|c|c|}
\hline 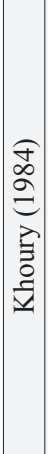 & 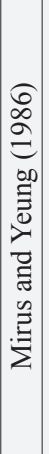 & 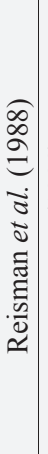 & 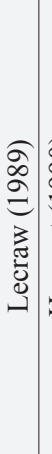 & 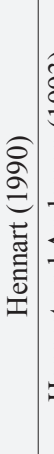 & 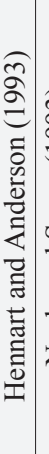 & 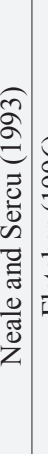 & 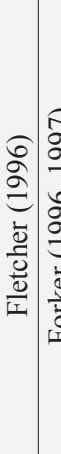 & 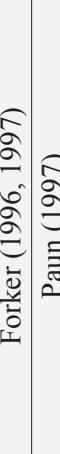 & 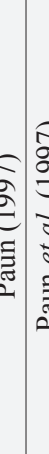 & 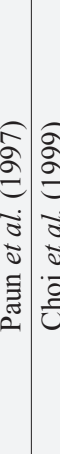 & 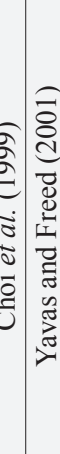 & 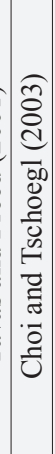 & 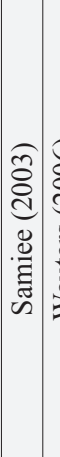 & 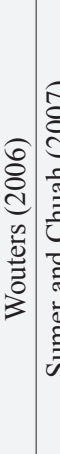 & 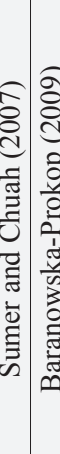 & 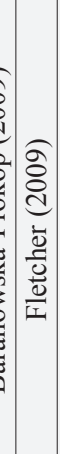 & 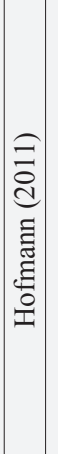 & 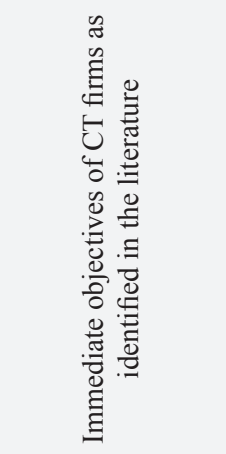 & 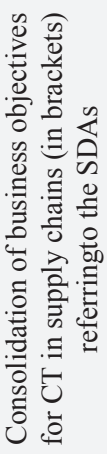 \\
\hline & $\mathrm{X}$ & & & & & & & & & & & & & & & & & $\begin{array}{c}\text { Exploit } \\
\text { technological } \\
\text { relationship } \\
\text { input/output }\end{array}$ & $\begin{array}{l}\mathrm{T} \& \mathrm{I} \\
(\mathrm{TA})\end{array}$ \\
\hline & $\mathrm{X}$ & & & & & & & & & & & & & & & & & $\begin{array}{l}\text { Exploit core } \\
\text { competence } \\
\text { in production } \\
\text { process }\end{array}$ & $\begin{array}{l}\mathrm{T} \& \mathrm{I} \\
(\mathrm{TA})\end{array}$ \\
\hline & $\mathrm{X}$ & & & & & & & & & X & $X$ & & & & $X$ & $\mathrm{X}$ & & $\begin{array}{c}\text { Resolve } \\
\text { uncertainty over } \\
\text { supplied quality }\end{array}$ & $\begin{array}{l}\text { T\&I } \\
(\mathrm{QC})\end{array}$ \\
\hline & & & $\mathrm{X}$ & & & & & & & X & $X$ & & & & & & & $\begin{array}{l}\text { Support trade in } \\
\text { high-technology } \\
\text { products }\end{array}$ & $\begin{array}{l}\text { T\&I } \\
(\mathrm{QC})\end{array}$ \\
\hline & & & & & & $X$ & & & & & & & & & & & & $\begin{array}{l}\text { Safeguard against } \\
\text { IP diffusion }\end{array}$ & $\begin{array}{l}\text { T\&I } \\
\text { (IPP) }\end{array}$ \\
\hline & $X$ & & $X$ & & & & & $X$ & & & & & $X$ & & & & & $\begin{array}{c}\text { Exploit } \\
\text { differential } \\
\text { transaction cost }\end{array}$ & $\begin{array}{l}\text { SCO } \\
\text { (TCR) }\end{array}$ \\
\hline & $\mathrm{X}$ & & & & $\mathrm{X}$ & & & $X$ & & & & & & & & & & $\begin{array}{l}\text { Circumvent state } \\
\text { foreign exchange } \\
\text { rationing }\end{array}$ & $\begin{array}{l}\text { SCO } \\
\text { (TCR) }\end{array}$ \\
\hline & & & & & & & & & & X & $X$ & & & & & & & $\begin{array}{c}\text { Avoid } \\
\text { measurement cost }\end{array}$ & $\begin{array}{l}\text { SCO } \\
\text { (TCR) }\end{array}$ \\
\hline & & $\mathrm{X}$ & & & & & & & & & & & & & $\mathrm{X}$ & & & $\begin{array}{l}\text { Optimize taxes } \\
\text { and tariffs }\end{array}$ & $\begin{array}{l}\mathrm{SCO} \\
\text { (TCR) }\end{array}$ \\
\hline & $\mathrm{X}$ & & $\mathrm{X}$ & & $\mathrm{X}$ & & & & & & & & & & & & & $\begin{array}{l}\text { Secure cost- } \\
\text { effective forward } \\
\text { contracts }\end{array}$ & $\begin{array}{l}\text { SCO } \\
\text { (ICR) }\end{array}$ \\
\hline & & & & & & $X$ & & X & $X$ & & & & & & & & & $\begin{array}{c}\text { Exploit } \\
\text { countertrade } \\
\text { capabilities }\end{array}$ & $\begin{array}{l}\text { SCO } \\
\text { (ICR) }\end{array}$ \\
\hline
\end{tabular}

SDA Marketing \& sales, M\&S: Volume management (VM), pricing (P) and new product support (NPS). SDA Network relationships, NRS: Bargaining power (BP), market access (MA) and incentives alignment (IA). SDA Technology \& innovation, T\&I: Technology access (TA), quality control (QC) and intellectual property protection (IPP). SDA Supply chain operations, SCO: Transaction cost reduction (TCO), input cost reduction (ICR) and supply chain resilience (SCR). 
Appendix 1. Continued...

\begin{tabular}{|l|l|l|l|l|l|l|l|l|l|l|l|l|l|c|c|c|}
\hline & \\
\hline
\end{tabular}

SDA Marketing \& sales, M\&S: Volume management (VM), pricing (P) and new product support (NPS). SDA Network relationships, NRS: Bargaining power (BP), market access (MA) and incentives alignment (IA). SDA Technology \& innovation, T\&I: Technology access (TA), quality control (QC) and intellectual property protection (IPP). SDA Supply chain operations, SCO: Transaction cost reduction (TCO), input cost reduction (ICR) and supply chain resilience (SCR). 
Appendix 2. Literature review on AHP in SCM.

The literature review is based on a search for articles in data bases incl. ProQuest and EBSCO. The terms used were: AHP and supply chain as well as analytical hierarchy process and, supply chain.

Appendix 2. AHP in SCM literature ranked by year and author.

\begin{tabular}{|c|c|c|c|c|}
\hline 2006 & 2007 & 2008 & 2009 & 2010 \\
\hline $\begin{array}{c}\text { Cao (2006); } \\
\text { Gaudenzi and } \\
\text { Borghesi (2006); } \\
\text { Gnanasekaran et al. } \\
\text { (2006); Kodali and } \\
\text { Routroy (2006); } \\
\text { Sha and Che } \\
\text { (2006); } \\
\text { Wu et al. }(2006)\end{array}$ & $\begin{array}{l}\text { Baramichai (2007); } \\
\text { Baramichai et al. } \\
\text { (2007); Berrah and } \\
\text { Clivillé (2007); } \\
\text { Bhagwat and } \\
\text { Sharma (2007a, b); } \\
\text { Chan et al. } \\
\text { (2007a, b); } \\
\text { Chen and Huang } \\
\text { (2007); Göl and } \\
\text { Catay (2007); } \\
\text { Haq and Kannan } \\
\text { (2007); Kanda and } \\
\text { Deshmukh (2007); } \\
\text { Levary (2007); } \\
\text { Lu et al. (2007); } \\
\text { Mendoza (2007); } \\
\text { Naesens et al. } \\
\text { (2007); } \\
\text { Rabelo et al. } \\
\text { (2007); } \\
\text { Ramanathan } \\
\text { (2007); } \\
\text { Sevkli et al. } \\
\text { (2007); }\end{array}$ & $\begin{array}{c}\text { Chan et al. } \\
\text { (2008); } \\
\text { Drzymalski } \\
\text { (2008); } \\
\text { Kannan et al. } \\
\text { (2008a, b); } \\
\text { Kengpol (2008); } \\
\text { Kinra and } \\
\text { Kotzab (2008); } \\
\text { Kuei et al. } \\
\text { (2008); Kull and } \\
\text { Talluri (2008); } \\
\text { Kumar and } \\
\text { Bisson (2008); } \\
\text { Levary (2008); } \\
\text { Liu } \text { et al. (2008); } \\
\text { Lorentz (2008); } \\
\text { Parthiban } \text { et al. } \\
\text { (2008); Sarker } \\
\text { and Zahir (2008); } \\
\text { Schoenherr et al. } \\
\text { (2008); Selçuk } \\
\text { (2008); } \\
\text { Sevkli et al. } \\
\text { (2008); Sheu } \\
\text { (2008); Ting } \\
\text { and Cho (2008); } \\
\text { Tsai et al. } \\
\text { (2008); Tzong- } \\
\text { Ru et al. (2008); } \\
\text { Varma et al. } \\
\text { (2008); Yan et al. } \\
\text { (2008) }\end{array}$ & $\begin{array}{c}\text { Bahinipati et al. } \\
\text { (2009); } \\
\text { Bhagwat and } \\
\text { Sharma (2009); } \\
\text { Enyinda (2009); } \\
\text { Kannan (2009); } \\
\text { Kannan } \text { et al. } \\
\text { (2009); } \\
\text { Routroy (2009); } \\
\text { Tsai and Hung } \\
\text { (2009) }\end{array}$ & $\begin{array}{l}\text { Brintrup (2010); } \\
\text { Che (2010); } \\
\text { Chen and } \\
\text { Wu (2010); } \\
\text { Ho et al. (2010); } \\
\text { Kuo et al. } \\
\text { (2010); Rao and } \\
\text { Patel (2010); } \\
\text { Sarmiento and } \\
\text { Thomas (2010); } \\
\text { Sen et al. } \\
\text { (2010); } \\
\text { Sherwat (2010); } \\
\text { Vijayvargiya } \\
\text { and Dey (2010) }\end{array}$ \\
\hline
\end{tabular}


Appendix 3. Case illustration.

Appendix 3. Exemplary weightings at the different levels of CT deals.

\begin{tabular}{c|} 
Automobile industry case \\
Perspective: Tier-1 supplier
\end{tabular}

Level I - Comparison on SDA level

\begin{tabular}{|c|c|c|c|c|c|}
\hline SDA & M\&S & NRM & T\&I & SCO & Weight \\
\hline M\&S & $\mathbf{1}$ & 2.00 & 1.00 & 0.33 & 0.207 \\
\hline NRM & 0.50 & $\mathbf{1}$ & 0.50 & 0.50 & 0.138 \\
\hline T\&I & 1.00 & 2.00 & $\mathbf{1}$ & 0.50 & 0.224 \\
\hline SCO & 3.00 & 2.00 & 2.00 & $\mathbf{1}$ & 0.431 \\
\hline & & & & C.R. & 0.044 \\
\hline
\end{tabular}

Level II - Comparison on objectives level

\begin{tabular}{|c|c|c|c|c|}
\hline M\&S & VM & P & NPS & Weight \\
\hline VM & $\mathbf{1}$ & 1.00 & 4.00 & 0.433 \\
\hline P & 1.00 & $\mathbf{1}$ & 5.00 & 0.466 \\
\hline NPS & 0.25 & 0.20 & $\mathbf{1}$ & 0.100 \\
\hline & & & C.R. & 0.005 \\
\hline
\end{tabular}

\begin{tabular}{|c|c|c|c|c|}
\hline T\&I & TA & QC & IPP & Weight \\
\hline TA & $\mathbf{1}$ & 1.00 & 5.00 & 0.466 \\
\hline QC & 1.00 & $\mathbf{1}$ & 4.00 & 0.433 \\
\hline IPP & 0.20 & 0.25 & $\mathbf{1}$ & 0.100 \\
\hline & & & C.R. & 0.005 \\
\hline
\end{tabular}

\begin{tabular}{|c|c|c|c|c|}
\hline NRM & BP & IA & IA & Weight \\
\hline BP & $\mathbf{1}$ & 0.50 & 2.00 & 0.297 \\
\hline MA & 2.00 & $\mathbf{1}$ & 3.00 & 0.540 \\
\hline IA & 0.50 & 0.33 & $\mathbf{1}$ & 0.163 \\
\hline & & & C.R. & 0.052 \\
\hline
\end{tabular}

\begin{tabular}{|c|c|c|c|c|}
\hline SCO & TCR & ICR & SCR & Weight \\
\hline TCR & $\mathbf{1}$ & 1.00 & 0.33 & 0.210 \\
\hline ICR & 1.00 & $\mathbf{1}$ & 0.50 & 0.240 \\
\hline SCR & 3.00 & 2.00 & $\mathbf{1}$ & 0.550 \\
\hline & & & C.R. & 0.018 \\
\hline
\end{tabular}

Level III - Comparison on CT alternatives level

\section{Marketing \& sales}

\begin{tabular}{|c|c|c|c|c|}
\hline VM & CA & OpBB & CIBB & Weight \\
\hline CA & $\mathbf{1}$ & 0.33 & 0.25 & 0.122 \\
\hline OpBB & 3.00 & $\mathbf{1}$ & 0.50 & 0.320 \\
\hline CIBB & 4.00 & 2.00 & $\mathbf{1}$ & 0.558 \\
\hline & & & C.R. & 0.018 \\
\hline
\end{tabular}

\begin{tabular}{|c|c|c|c|c|}
\hline $\mathbf{P}$ & $\mathrm{CA}$ & $\mathrm{OpBB}$ & $\mathrm{CIBB}$ & Weight \\
\hline $\mathrm{CA}$ & $\mathbf{1}$ & 3.00 & 2.00 & 0.540 \\
\hline OpBB & 0.33 & $\mathbf{1}$ & 0.50 & 0.163 \\
\hline CIBB & 0.50 & 2.00 & $\mathbf{1}$ & 0.297 \\
\hline & & & C.R. & 0.009 \\
\hline
\end{tabular}

\section{Network relationships}

\begin{tabular}{|c|c|c|c|c|}
\hline BP & CA & OpBB & CIBB & Weight \\
\hline CA & $\mathbf{1}$ & 0.25 & 0.20 & 0.100 \\
\hline OpBB & 4.00 & $\mathbf{1}$ & 1.00 & 0.433 \\
\hline CIBB & 5.00 & 1.00 & $\mathbf{1}$ & 0.466 \\
\hline & & & C.R. & 0.005 \\
\hline
\end{tabular}

\begin{tabular}{|c|c|c|c|c|}
\hline MA & CA & OpBB & CIBB & Weight \\
\hline CA & $\mathbf{1}$ & 0.50 & 0.33 & 0.163 \\
\hline OpBB & 2.00 & $\mathbf{1}$ & 0.50 & 0.297 \\
\hline CIBB & 3.00 & 2.00 & $\mathbf{1}$ & 0.540 \\
\hline & & & C.R. & 0.009 \\
\hline
\end{tabular}


Appendix 3. Continued...

\begin{tabular}{|c|c|c|c|c|}
\hline NPS & CA & OpBB & CIBB & Weight \\
\hline CA & $\mathbf{1}$ & 0.33 & 0.25 & 0.117 \\
\hline OpBB & 3.00 & $\mathbf{1}$ & 0.33 & 0.268 \\
\hline CIBB & 4.00 & 3.00 & $\mathbf{1}$ & 0.614 \\
\hline & & & C.R. & 0.071 \\
\hline
\end{tabular}

\begin{tabular}{|c|c|c|c|c|}
\hline IA & CA & OpBB & CIBB & Weight \\
\hline CA & $\mathbf{1}$ & 0.33 & 0.25 & 0.122 \\
\hline OpBB & 3.00 & $\mathbf{1}$ & 0.50 & 0.320 \\
\hline CIBB & 4.00 & 2.00 & $\mathbf{1}$ & 0.558 \\
\hline & & & C.R. & 0.018 \\
\hline
\end{tabular}

Technology \& innovation

\begin{tabular}{|c|c|c|c|c|}
\hline TA & CA & OpBB & CIBB & Weight \\
\hline CA & $\mathbf{1}$ & 0.50 & 0.20 & 0.128 \\
\hline OpBB & 2.00 & $\mathbf{1}$ & 0.50 & 0.276 \\
\hline CIBB & 5.00 & 2.00 & $\mathbf{1}$ & 0.595 \\
\hline & & & C.R. & 0.005 \\
\hline
\end{tabular}

\begin{tabular}{|c|c|c|c|c|}
\hline QC & CA & OpBB & CIBB & Weight \\
\hline CA & $\mathbf{1}$ & 0.25 & 0.33 & 0.126 \\
\hline OpBB & 4.00 & $\mathbf{1}$ & 1.00 & 0.458 \\
\hline CIBB & 3.00 & 1.00 & $\mathbf{1}$ & 0.416 \\
\hline & & & C.R. & 0.009 \\
\hline
\end{tabular}

\begin{tabular}{|c|c|c|c|c|}
\hline IPP & CA & OpBB & CIBB & Weight \\
\hline CA & $\mathbf{1}$ & 5.00 & 3.00 & 0.648 \\
\hline OpBB & 0.20 & $\mathbf{1}$ & 0.50 & 0.122 \\
\hline CIBB & 0.33 & 2.00 & $\mathbf{1}$ & 0.230 \\
\hline & & & C.R. & 0.004 \\
\hline
\end{tabular}

\section{Supply chain operations}

\begin{tabular}{|c|c|c|c|c|}
\hline TCR & CA & OpBB & CIBB & Weight \\
\hline CA & $\mathbf{1}$ & 0.25 & 3.00 & 0.226 \\
\hline OpBB & 4.00 & $\mathbf{1}$ & 5.00 & 0.674 \\
\hline CIBB & 0.33 & 0.20 & $\mathbf{1}$ & 0.101 \\
\hline & & & C.R. & 0.082 \\
\hline
\end{tabular}

\begin{tabular}{|c|c|c|c|c|}
\hline ICR & CA & OpBB & CIBB & Weight \\
\hline CA & $\mathbf{1}$ & 0.25 & 2.00 & 0.208 \\
\hline OpBB & 4.00 & $\mathbf{1}$ & 4.00 & 0.661 \\
\hline CIBB & 0.50 & 0.25 & $\mathbf{1}$ & 0.131 \\
\hline & & & C.R. & 0.052 \\
\hline
\end{tabular}

\begin{tabular}{|c|c|c|c|c|}
\hline SCR & CA & OpBB & CIBB & Weight \\
\hline CA & $\mathbf{1}$ & 0.20 & 0.50 & 0.128 \\
\hline OpBB & 5.00 & $\mathbf{1}$ & 2.00 & 0.595 \\
\hline CIBB & 2.00 & 0.50 & $\mathbf{1}$ & 0.276 \\
\hline & & & C.R. & 0.005 \\
\hline
\end{tabular}

\section{Calculation of global priorities}

\begin{tabular}{|c|c|c|c|c|c|c|}
\cline { 2 - 7 } \multicolumn{1}{c|}{} & \multicolumn{4}{c|}{ M\&S } & \multicolumn{3}{c|}{ NRM } \\
\cline { 2 - 7 } & \multicolumn{3}{c|}{0.207} & \multicolumn{3}{c|}{0.138} \\
\cline { 2 - 7 } & VM & P & NPS & BP & MA & IA \\
\cline { 2 - 7 } & 0.433 & 0.466 & 0.100 & 0.297 & 0.540 & 0.163 \\
\hline Compensation deal & 0.122 & 0.540 & 0.117 & 0.100 & 0.163 & 0.122 \\
\hline Operating buy-back & 0.320 & 0.163 & 0.268 & 0.433 & 0.297 & 0.320 \\
\hline Capital investmentbuy-back & 0.558 & 0.297 & 0.614 & 0.466 & 0.540 & 0.558 \\
\hline
\end{tabular}


Appendix 3. Continued...

\begin{tabular}{|c|c|c|c|c|c|c|}
\cline { 2 - 7 } \multicolumn{1}{c|}{} & \multicolumn{3}{c|}{ T\&I } & \multicolumn{3}{c|}{ SCO } \\
\cline { 2 - 7 } & \multicolumn{3}{c|}{0.224} & \multicolumn{3}{c|}{0.431} \\
\cline { 2 - 7 } & TA & QC & IPP & TCR & ICR & SCR \\
\cline { 2 - 7 } & 0.466 & 0.433 & 0.100 & 0.210 & 0.240 & 0.550 \\
\hline Compensation deal & 0.128 & 0.126 & 0.648 & 0.226 & 0.208 & 0.128 \\
\hline Operating buy-back & 0.276 & 0.458 & 0.122 & 0.674 & 0.661 & 0.595 \\
\hline Capital investmentbuy-back & 0.595 & 0.416 & 0.230 & 0.101 & 0.131 & 0.276 \\
\hline
\end{tabular}

\section{Ideal CT deal structure}

\begin{tabular}{|c|c|c|}
\cline { 2 - 3 } \multicolumn{1}{c|}{} & Priority & Idealized \\
\hline Compensation deal & 0.197 & $\mathbf{4 4 \%}$ \\
\hline Operating buy-back & 0.444 & $\mathbf{1 0 0 \%}$ \\
\hline Capital investment buy-back & 0.359 & $\mathbf{8 1 \%}$ \\
\hline
\end{tabular}

